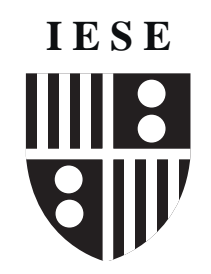

University of Navarra

\title{
GOVERNANCE MECHANISMS FOR EFFECTIVE LEADERSHIP: \\ THE CASE OF SPAIN
}

\author{
Joan E. Ricart* \\ José L. Alvarez* \\ Miguel A. Gallo* \\ RESEARCH PAPER No 371 \\ November, 1998 \\ * Professors of General Management, IESE
}

Research Division IESE

University of Navarra Av. Pearson, 21

08034 Barcelona - Spain 


\title{
GOVERNANCE MECHANISMS FOR EFFECTIVE LEADERSHIP: THE CASE OF SPAIN
}

\begin{abstract}
Most recent work on Boards of Directors has been focused on what can be considered best practices for effective governance in terms of roles, composition, process and style. Furthermore, this literature can be divided among very practically oriented managerial work, and more rigorous, theoretically based work. Most of the empirical research in this area has been centered on Anglo-Saxon countries. Some European countries, like Spain, have a very different governance tradition. Given this context, our present work pursues three complementary objectives: 1. To ascertain the current status of governance practices in Spain. 2. To obtain evidence about which of these practices may be associated with effective governance. 3 . To find out what factors account for the composition of General Managers' compensation.
\end{abstract}




\section{GOVERNANCE MECHANISMS FOR EFFECTIVE LEADERSHIP: THE CASE OF SPAIN}

\section{Introduction}

Most recent work on Boards of Directors has been focused on what can be considered best practices for effective governance. These practices correspond to:

1) The role of the Board as a governance body (strategy, control, development of the top management team,...). For representative work on this, see Zahra (1990), Donaldson (1995), Johnson, Hoskinsson and Hitt (1993), Daily (1996) or Parker (1996);

2) Elements of the Board's composition (such as the number of directors, the number of independent directors, the number of executive directors, dual leadership,...). Here, the relevant literature is very extensive; for instance, Daily and Dalton (1994), Zahra and Pearce (1989), Baysinger and Hoskinsson (1990) or Hill (1995);

3) Characteristics of the Board (such as background of directors, gender, minorities, diversity,...), as in Provan (1980), Kosnik (1987) or Molz (1988); and

4) Process and style of the Board (committees, number of meetings, length of meetings, information sent before meetings,...) as in Kesner (1988), Meuter (1995) or Lear (1995).

However, to associate any of these elements to better company performance has not been an easy task. For instance, the effect of Board size on performance has been studied by Pfeffer (1973), Provan (1980) and Zahra and Stanton (1988). The effect of insider/outsider composition has been studied by Vance (1964), Schmidt (1975), Schmidt (1977), Kesner (1987), Chaganti et al. (1985), Cochran, Wood and Jones (1985), Kesner, Victor and Lamont (1986), Baysinger and Butler (1985), Pearce and Zahra (1992), Daily and Johnson (1997), and Zahra and Stanton (1988). Some of this work finds a positive relationship, some no significance, and some a negative relationship. The effect of the Board's characteristics on performance has been studied by Vance (1978), Pearce (1983) and Norburn (1986). Structure and performance are related in Rechner and Dalton (1991); and process and performance are studied in Miller and Norburn (1986) and in Zahra and Pearce (1987). In a recent meta-analytical review (Dalton et al., 1998), the authors conclude that there is no meaningful relationship between Board composition or Board leadership structure and financial performance.

Furthermore, the literature can be divided between very practically oriented managerial work, usually based on the real experience of people on Boards (Vander Weyer, 1995; Park, 1995; Kesner and Johnson, 1990; Useem et al., 1993; and Lorsch and MacIver, 
1989), and more rigorous, theoretically based work, usually very unrelated to real practice, and with most of the empirical research in this area centered in Anglo-Saxon countries (like most of the studies quoted above). Some European countries, like Spain, have a very different governance tradition less centered on the stock system and institutional investors, making it very difficult to generalize results from other countries. Gedajlovic and Shapiro (1998) show that institutional differences across countries matter.

Given this context, our present work pursues three complementary objectives:

1. To ascertain the current status of governance practices in Spain.

2. To obtain evidence about which of these practices may be associated with effective governance.

3. To find out what factors account for the composition of General Managers' compensation.

To achieve these objectives, we designed and mailed a questionnaire to more than 5000 large and medium-sized firms in Spain. We selected all firms with more than 150 employees or sales revenues (in 1995) exceeding 3000 million pesetas. We received 498 answers from a variety of sizes and types of companies in different industries. Most of the questionnaires were answered directly by the company's President or CEO. The sample is very representative of Spanish companies, covering about 3.7\% of the Spanish workforce and selling all together more than 10 trillion pesetas.

The questionnaire covered a wide range of issues from general data to the composition, style and characteristics of the Board of Directors and Executive Committee, the tasks and roles of each governance body, including the CEO, organizational structure, and appraisal and compensation of the Top Management Team.

This paper covers the three objectives stated above in the following way:

1. First, we present some descriptive statistics that show and analyze the current situation of governance practices in Spain. In general, the governance practices used in Spain are less advanced than those described in most Anglo-Saxon studies. Structures are less sophisticated, many Boards are still not very active, and even the active ones do not meet very often, nor do they receive enough information.

2. The study reveals that the Board of Directors' activity on its own is not directly associated with more effective governance. When a powerful Board of Directors is combined with a powerful CEO, one finds the Board attribute usually associated with good governance practices, as in Pearce and Zahra (1991). However, the link between these practices and greater profitability cannot be confirmed.

3. We also study the effect of different governance elements and practices with regard to executive appraisal and compensation, specially CEO compensation. Appraisal and compensation practices in Spain are not very sophisticated. We study the composition of CEO compensation (behavior-based vs. results-based) in depth and look at how it is affected by the following factors: 
- The monitoring role of the Board of Directors as measured by its level of activity.

- The Board of Directors' composition as measured by the number of independent Board members.

- The discretion of the CEO and the measurability of results, as measured by the industry, the type of organizational structure, and stock market listing.

- Risk considerations, as measured by company size and type of ownership (family business, State-owned enterprise or other).

Finally, we study the relationship between the composition of the CEO's compensation and the company's financial performance.

This study is unique both because of the nature and size of the sample used and also because it is the first comprehensive study of governance practices in Spain.

\section{The questionnaire and the sample}

The information needed to carry out the research was obtained by means of a questionnaire (reproduced in Appendix 1). This questionnaire was sent to a total of 5,565 companies. 498 companies answered it, giving a response rate of $9 \%$.

The survey was sent to large and medium-sized companies. Specifically, the universe was obtained from the Dun \& Bradstreet database, taking the 5,565 companies that had billed more than 3,000 million pesetas in 1995 or that had more than 150 employees in that year (or that met both criteria simultaneously).

The 498 companies that answered the questionnaire had a combined sales turnover of 10.1 trillion pesetas and a total of 444,948 employees $(3.7 \%$ of the Spanish workforce in 1995). Therefore, it is probably the largest sample ever obtained for the purpose of researching governance practices in Spain.

Some cautions are necessary about the questionnaire. The questionnaire was sent either to the Chairman or to the CEO. Thus, although only one person filled in the questionnaire, his/her position can be considered high enough to give him/her an overall view of the company. As we can see in Table 2.1, this is the case in our sample. Fourteen percent of those who answered were Chairman of the Board of Directors, 55\% were CEOs, and only in $13 \%$ of the cases did another manager answer the questionnaire. 
Table 2.1 Who answered the questionnaire?

\begin{tabular}{|l|r|}
\hline Chairman of the Board of Directors & $14 \%$ \\
\hline CEO & $55 \%$ \\
\hline Advisor & $11 \%$ \\
\hline Manager & $13 \%$ \\
\hline Other & $6 \%$ \\
\hline
\end{tabular}

With respect to the questionnaire's contents, at the time of compiling the quantitative data, it was observed that there had been confusion in some cases between operating companies and groups. In addition, the results were requested with reference to only one year. This meant that the data do not give the complete picture. Any governance practice takes time to produce results. An earlier governance practice may continue to influence results today. Similarly, a current practice will affect results in the future. Consequently, it is unwise to relate governance practices and results in the same period. Also, given the data requested in the survey, we can only calculate profitability using the Profits/Sales ratio.

We have classified the data for analysis in three ways:

1) Type of ownership, depending on whether the company is a Family business, a State-owned enterprise, a Subsidiary of a foreign multinational, or a Nonfamily-owned Spanish company, which we have called "Non-family". The person who answered the questionnaire self-classified his/her company.

2) Type of structure, which can be functional, divisional or matrix/network.

3) Size by number of employees or sales.

We analyzed the relationship between size and type of ownership, and between size and organizational structure. The purpose of this was to assure the sample's validity (Table 2.2). It can be seen that the State-owned and Family companies are smaller than the other types. By type of structure, the functional companies are smallest.

Table 2.2 Relationship between size and type of ownership and structure

\begin{tabular}{|l|c|c|c|c|}
\hline \multirow{2}{*}{ Av e rage e } & \multicolumn{4}{|c|}{ Type of ownership } \\
\cline { 2 - 5 } & Multinational & State-owned & Family & Non-family \\
\hline Employees & 765.94 & $1,050.29$ & 565.81 & $1,384.32$ \\
\hline Sales* & $22,205.30$ & $\mathbf{1 0 , 9 8 8 . 3}$ & $\mathbf{1 1 , 8 6 7 . 2}$ & $18,096.30$ \\
\hline & \multicolumn{4}{|c|}{ Type of structure } \\
\cline { 2 - 5 } & & Functional & Divisional & Matrix \\
\hline Employees & & $\mathbf{4 8 1 . 9}$ & 992.7 & $1,077.70$ \\
\hline Sales* & & $\mathbf{1 1 , 9 1 2 . 6 0}$ & $20,642.60$ & $24,518.60$ \\
\hline
\end{tabular}


We checked for differences in profitability and productivity according to the above typology (structure, ownership and size). We used the Profit/Sales ratio as an indicator of profitability. The average for the total sample is $6.35 \%$, with a standard deviation of $6.4 \%$. We found no statistically significant differences, as can be seen in Table 2.3.

Table 2.3 Profitability by Type of Ownership

\begin{tabular}{|l|r|r|r|r|r|}
\hline \multirow{2}{*}{} & \multicolumn{5}{|c|}{ Profits / Sales } \\
\cline { 2 - 7 } & \multicolumn{5}{|c|}{ Type of ownership } \\
\hline & Multinational & State-owned & Family & Non-family & Total \\
\hline Number of companies & 133 & 24 & 94 & 106 & 357 \\
\hline Average profitability & 0.0604 & 0.0873 & 0.0581 & 0.06669 & 0.0635 \\
\hline Standard deviation & 0.0512 & 0.0967 & 0.06162 & 0.07 & 0.06415 \\
\hline$z$ & -0.06134 & 0.2456 & -0.08852 & 0.04467 & \\
\hline
\end{tabular}

Another of the ratios studied is the Sales Turnover/Employee as an indicator of productivity. The overall average is 45.9 million pesetas per employee. We looked for significant differences based on type of ownership, type of structure, and size. The only statistically significant difference we found (Table 2.4) is that average sales per employee in the Family businesses was 30.8 million, whereas in Non-family and Multinational companies it was over 51 million.

As a possible explanation of this result, it should be remembered that, at the present time, most Family businesses are still located in labor-intensive industries. This result confirms that while Family businesses are following the trend in Europe of increasing sales per employee, they are still some years behind.

Table 2.4 Productivity and Type of Ownership

\begin{tabular}{|l|r|r|r|r|r|}
\hline & \multicolumn{5}{|c|}{ Sales (in mill PTAs / Employee } \\
\hline & \multicolumn{5}{|c|}{ Type of Ownership } \\
\hline & Multinational & State-owned & Family & Non-family & \multicolumn{1}{c|}{ Total } \\
\hline Number of companies & 158 & 33 & $\mathbf{1 2 0}$ & 133 & 444 \\
\hline Average & 51.3 & 46.4 & $\mathbf{3 0 . 8}$ & 53.0 & 45.9 \\
\hline Standard deviation & 5.5 & 14.9 & $\mathbf{2 . 7}$ & 6.5 & 3.1 \\
\hline $\mathrm{z}$ & -0.85 & -0.03 & $\mathbf{3 . 6 4}$ & -0.98 & \\
\hline
\end{tabular}

$\mathrm{p}<0.05$ 


\section{Governance practices in Spain}

From the data in the questionnaire, taking into account the representativeness of the sample, we were able to draw a clear picture of governance practices in Spain. In this section, we present a summary of the descriptive data. First, we present data on Boards of Directors. Second, on Executive Committees. Third, on the CEO. And fourth, a balanced account of all three governance bodies.

\section{Board of Directors}

A key question concerns the Board's level of "activity". Specifically, we asked whether the companies have an active Board or whether they do not have a Board at all; whether the Board has been formed purely to meet legal requirements and is not active; or whether it is only nominal and has no influence. We have aggregated the latter three alternatives under the label "non-active".

Table 3.1 (a) presents the data on the level of activity. It is interesting to see that, overall, $42 \%$ of the companies have non-active Boards. We found significant differences depending on the type of ownership and structure. Before analyzing these differences, however, we studied how some of the Board's characteristics depended on the level of activity. Table 3.1 (b) shows the significant differences.

First, we see that size has a significant effect on the level of activity, and yet the average size of non-active Boards is very large. Second, we see some composition differences. Active Boards are larger, with both more insiders and more outsiders, but with a larger ratio of outsiders to the total (59\% vs. 52\%). Third, with regard to process, active Boards meet more often (8.2 times vs. 3.7) and for a longer overall time (26.7 vs. 13.3 hours a year). However, no significant differences in terms of profitability have been identified.

Finally, when looking for differences in structure, we find that the percentage of active Boards of Directors is above average in the companies with a divisional structure, and below average in the companies with a functional structure. The reason for this could be that companies adopt a divisional structure when they reach a large size and operate in a wide variety of businesses. In these circumstances, a significant decision dynamic is generated that usually requires a greater degree of Board activity. On the other hand, the higher percentage of passive Boards of Directors among the functional companies may be due to the family businesses, which have a higher concentration in this type of structure.

Table 3.1 (a) Level of Board activity

\begin{tabular}{|l|c|c|c|c|c|c|c|c|}
\hline \multirow{2}{*}{$\begin{array}{l}\text { Level of Board } \\
\text { Activity }\end{array}$} & \multicolumn{4}{|c|}{ Type of Ownership* } & \multicolumn{3}{c|}{ Type of Structure** } \\
\hline & & Multinational & State-owned & Family & Non-family & Functional & Divisional & Matrix \\
\hline Active & $58 \%$ & $42 \%$ & $72 \%$ & $51 \%$ & $78 \%$ & $37 \%$ & $48 \%$ & $15 \%$ \\
\hline Non-Active & $42 \%$ & $58 \%$ & $28 \%$ & $49 \%$ & $22 \%$ & $48 \%$ & $35 \%$ & $17 \%$ \\
\hline
\end{tabular}

$* \mathrm{p}<0.0001$

$* * \times 2_{2}=0.01 ; \mathrm{p}<0.01$ 
Table 3.1 (b) Different characteristics according to level of Board activity

\begin{tabular}{|l|c|c|c|}
\hline \multicolumn{1}{|c|}{$\begin{array}{c}\text { Differential } \\
\text { Factor }\end{array}$} & $\begin{array}{c}\text { Active } \\
\text { Board }\end{array}$ & $\begin{array}{c}\text { Non-Active } \\
\text { Board }\end{array}$ & Statistic \\
\hline $\begin{array}{l}\text { The average number of } \\
\text { employees is higher in } \\
\text { companies with active boards }\end{array}$ & $\mathbf{1 , 2 5 6}$ & $\mathbf{4 9 8}$ & $\mathrm{p}<0.05$ \\
\hline $\begin{array}{l}\text { Average sales are higher in } \\
\text { companies with active boards }\end{array}$ & $\mathbf{1 9 , 1 7 1}$ & $\mathbf{1 5 , 1 0 9}$ & $\mathrm{p}<0.05$ \\
\hline $\begin{array}{l}\text { The number of directors is } \\
\text { higher in active boards }\end{array}$ & $\mathbf{8 . 6}$ & $\mathbf{6 . 0}$ & $\mathrm{p}<0.0001$ \\
\hline $\begin{array}{l}\text { The number of insiders is } \\
\text { higher in active boards }\end{array}$ & $\mathbf{3 . 5}$ & $\mathbf{2 . 9}$ & $\mathrm{p}<0.05$ \\
\hline $\begin{array}{l}\text { The number of outsiders is } \\
\text { higher in active boards }\end{array}$ & $\mathbf{5 . 1}$ & $\mathbf{3 . 1}$ & $\mathrm{p}<0.0001$ \\
\hline $\begin{array}{l}\text { The number of meetings is } \\
\text { higher in active boards }\end{array}$ & $\mathbf{8 . 2}$ & $\mathbf{3 . 7}$ & $\mathrm{p}<0.0001$ \\
\hline $\begin{array}{l}\text { The number of meeting hours } \\
\text { is higher in active boards }\end{array}$ & $\mathbf{1 3 . 3}$ & $\mathrm{p}<0.0001$ \\
\hline
\end{tabular}

As we said before, there is a higher percentage of active Boards of Directors among the non-family (78\%) and State-owned (72\%) companies, than among the family $(51 \%)$ and multinational (42\%) firms. One explanation for this may be the influence of the directors' "sense of ownership" and "freedom". Indeed, a multinational company that operates in Spain establishes itself legally as a company, but usually its operations are not governed by the Spanish company's Board of Directors, i.e. the Board exists to meet legal requirements (legal Board) or to represent the company to third parties (nominal Board). In this sense, the directors' freedom is limited by managers and by the parent company's policies.

A similar thing happens in family businesses, specially when they are in their first or second generation, as is the case with most Spanish family companies. In these companies, the leader -the company founder or his/her immediate successor- usually has a great deal of authority over the other members of the Board of Directors, and very often holds a majority or a very large percentage of the capital. This person's authority and power are used to limit, directly or indirectly, the other directors' freedom.

At the other extreme, in the non-family companies, directors, in their capacity as owners or direct representatives of the owners, exercise their rights freely and are motivated by their sense of ownership because, as owners, they are remunerated according to the company's performance. In consequence, they exercise their rights in an active Board. 
A similar argument can be applied to State-owned companies. Directors are not owners but are answerable to those who appointed them (usually members of the party in power). So, they tend to be active on the Board to demonstrate their ability to manage publicly-owned companies and the ability of the political group they represent.

The different levels of freedom and sense of ownership of the people who make up the Board help to explain, as shown in Figure 3.1, the degree of Board activity by type of ownership.

Figure 3.1 Active Boards, freedom and sense of responsibility

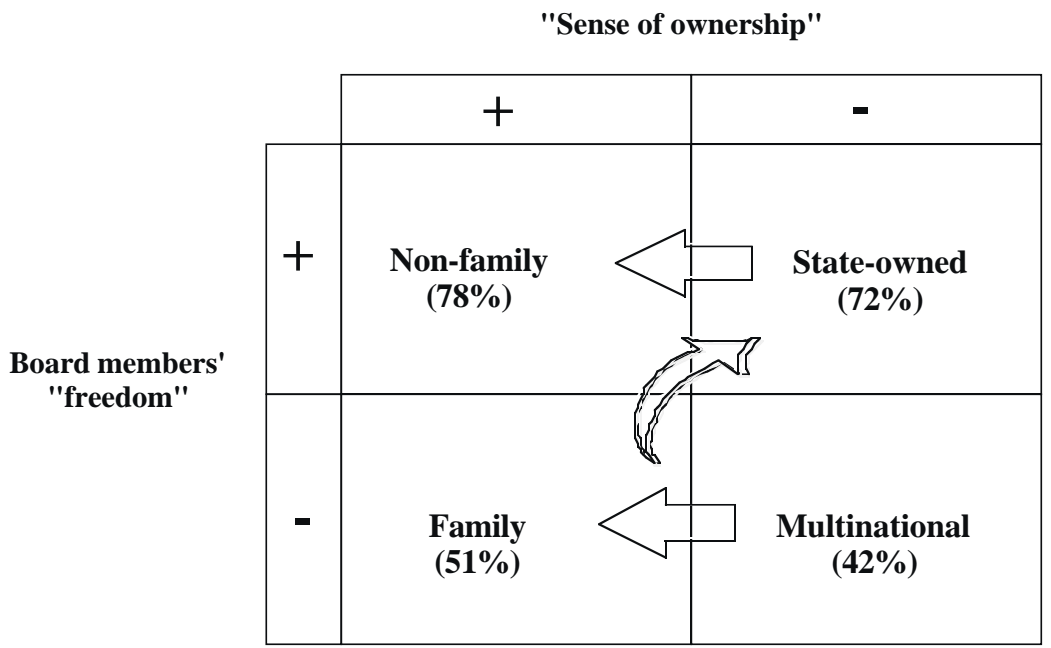

Overall, we see that the level of Board activity is very low. This is further confirmed if one analyzes the amount of time spent in Board meetings, the way this time is spent, and the information sent to Board members prior to meetings. The conclusion is that even active Boards are far from effective. This problem is basically related to Board members' sense of ownership and freedom of decision-making.

\section{Executive Committees}

We use the term Executive Committee (EC) to refer to the company's Top Management Team. While the Board of Directors has a very important governance role, a Management or Executive Committee is a fundamental integrative and learning instrument in governing a company.

In our sample, $84 \%$ of the companies have an EC. This result implies that there is still a substantial number of medium and large companies that do not have regular EC meetings. The proportion increases in the family businesses, $22 \%$ of which do not have an operative EC, and in the State-owned companies, where the figure is $23 \%$. If we compare the companies that have an EC with those that don't, we find that those without an EC are smaller and are significantly less profitable (3.7\% vs. $5.7 \%$ ) (Table 3.2$)$. 
Table 3.2 Executive Committee, size and profitability

\begin{tabular}{|c|c|c|c|}
\hline & Average Sales* & $\begin{array}{c}\text { Average } \\
\text { Profits/Sales* }\end{array}$ & $\begin{array}{c}\text { Percentage of } \\
\text { companies }\end{array}$ \\
\hline $\begin{array}{c}\text { With Executive } \\
\text { Committee }\end{array}$ & 18,707 & $5.7 \%$ & $84 \%$ \\
\hline $\begin{array}{c}\text { Without Executive } \\
\text { Committee }\end{array}$ & 10,978 & $3.7 \%$ & $16 \%$ \\
\hline$* \mathrm{p}<0.05$ & \multicolumn{3}{|c}{} \\
\cline { 2 - 4 }
\end{tabular}

We also studied the frequency of meetings. Table 3.3 shows the Executive Committees broken down according to the total number of hours spent in meetings in one year. We can see that the distribution frequency of meetings is bimodal. One third meets weekly, whereas another third meets monthly. This bimodality may indicate a very different use of the EC in either case. In one case they may actually act as an integrative management committee, while in the other they may be acting as an effective internal Board of Directors.

Table 3.3 Percentage of Committees according to hours spent in meetings in a year

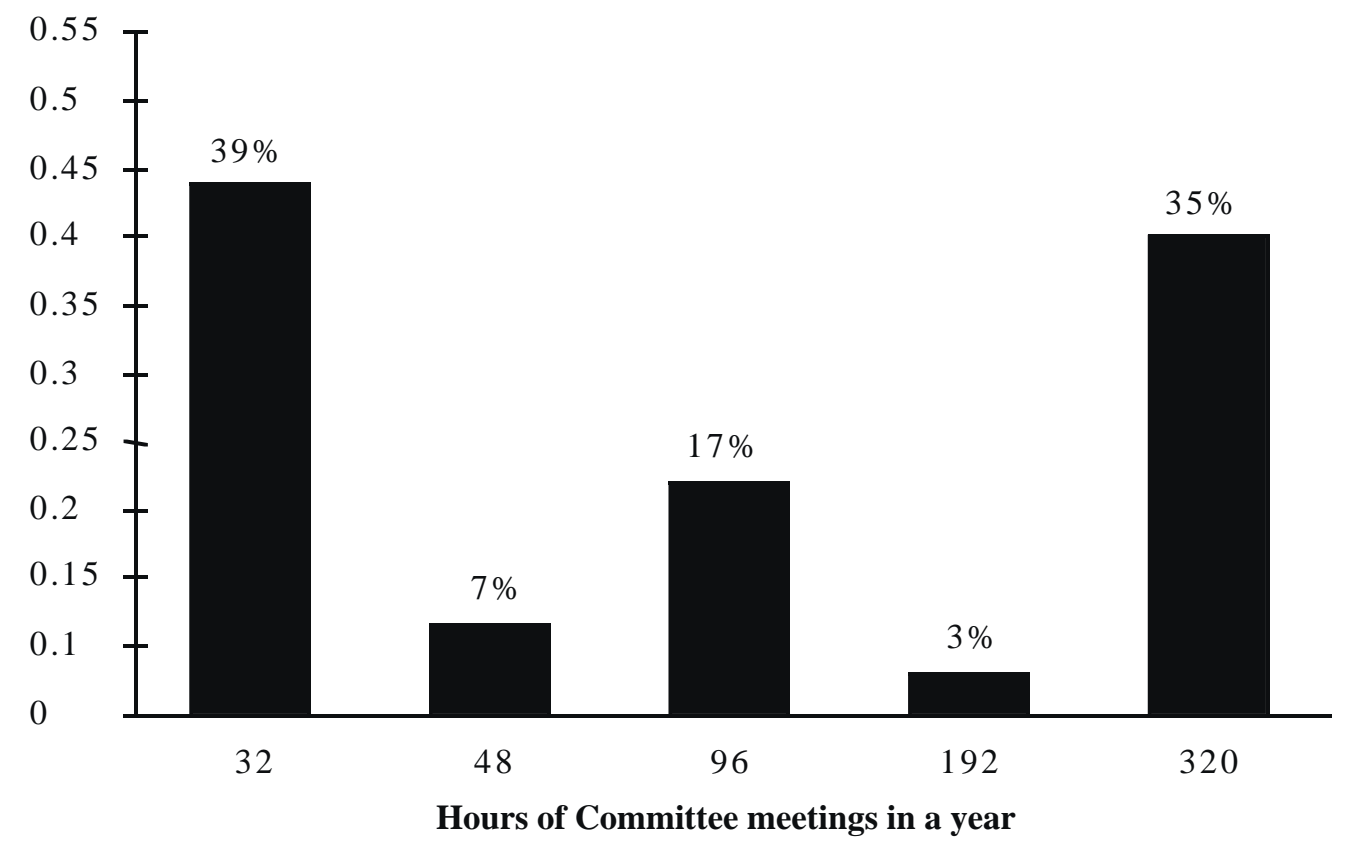

Finally, the information received by the committee members before meetings is limited and is strictly functional.

We have seen that although $84 \%$ of the companies have Executive Committees, there are still $16 \%$ that do not. In addition, we have seen that the use made of Executive 
Committees is very different. Therefore, we can conclude that, in Spain, Executive Committees are not used to their full extent. We have also found a clear link between the use of an EC and company performance.

\section{CEO}

The CEO's responsibilities in a company are very wide. In this section, we shall consider these responsibilities in a summarized form. According to Pearson (1985) (1), there are six areas that constitute the main tasks of a CEO:

1. Shaping the work environment.

2. Crafting a strategic vision.

3. Marshaling resources.

4. Developing star performers.

5. Organizational body building.

6. Managing operations.

While we did not have the necessary data to study the first task, we were able to study the CEO's involvement in the other five tasks.

We used a question listing 14 functions that are sufficiently representative of governance and management. The respondent had to indicate what role, if any, each governance body (Board, Committee, CEO) played in each of these functions, choosing between the following four roles: Approve, Decide, Propose, Inform. The aim was to ascertain the extent to which each governance body was involved in each task. We have used the answers to this question to calculate the CEO's degree of "power" and "activity" in five of the six tasks proposed by Pearson (as listed above). The method used is as follows: first, we assigned each of the 14 functions to one or other of the five basic tasks of a CEO. Second, we assumed that a CEO has "power" in a given task when he decides or approves it, and that he is "active" in a task when he plays any one of the four possible roles (approve, decide, propose, inform).

Thus, we have been able to study the CEO's influence in the related tasks. We have calculated the variables shown in Figure 3.2. On the one hand, we can see in the figure that the CEO's level of activity is quite high in all the tasks. This result was foreseeable: the CEO will be involved in most of the firm's areas.

On the other hand, the CEO's power has two different tendencies. First, there are three tasks where the CEO's power is high: managing operations, organizational body building, and developing star performers. This is consistent with the fact that these are basic CEO tasks. In contrast, there are two tasks where the CEO has less power: marshaling resources, and crafting a strategic vision. This is a clear indication of the increasing role being played by the Board of Directors in strategic management, a fact confirmed again in the following section, where this analysis is carried out in greater detail. 
Figure 3.2. A comparison of basic CEO tasks

\section{Basic CEO Tasks}

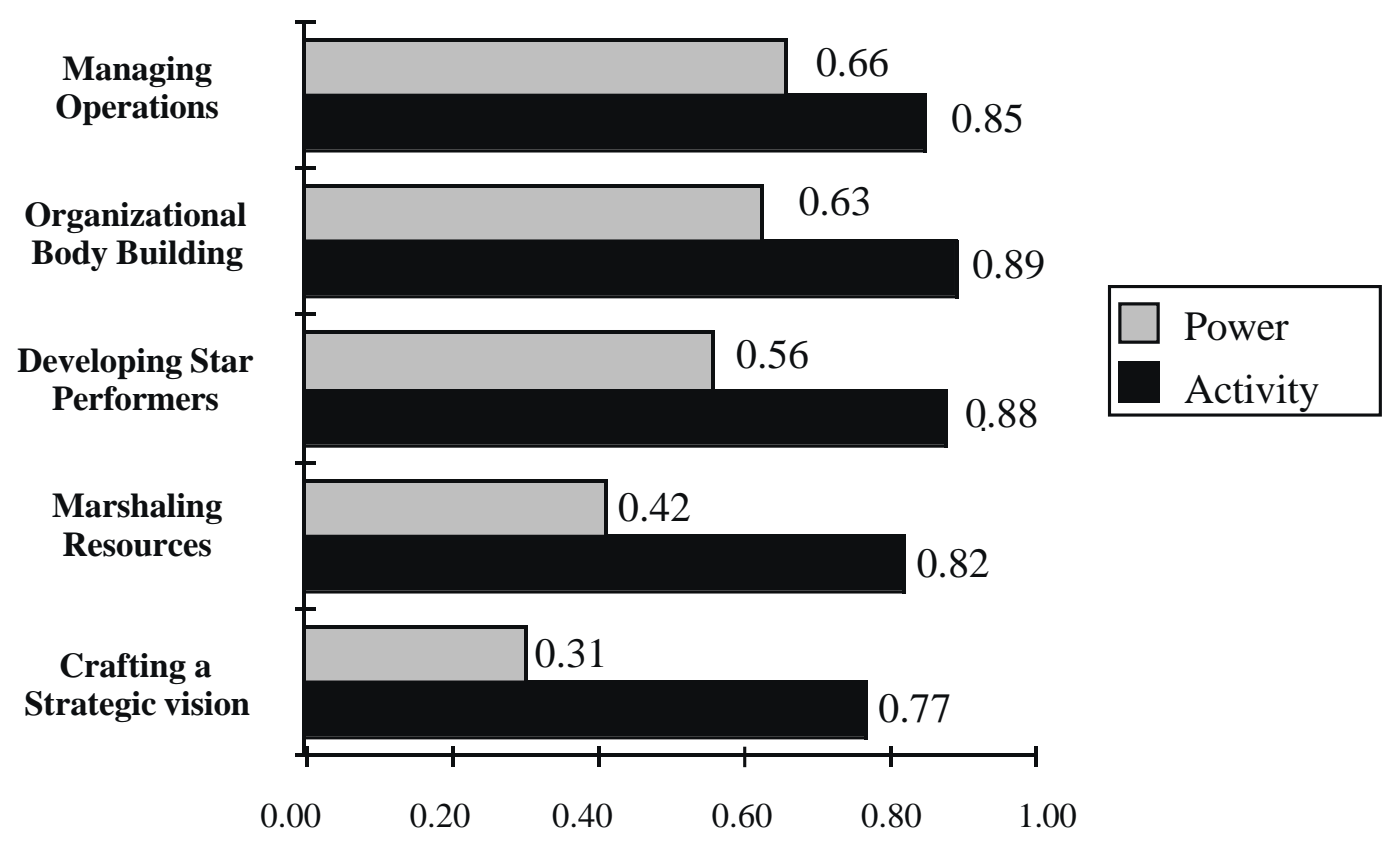

The relative power of the three governance bodies

After analyzing the three governance bodies separately, it could be interesting to study them together. Specifically, through the question already used in the CEO section, our purpose is to study the "activity" and "power" of each of these bodies in fourteen key decision areas.

The questionnaire presented 14 functions that are sufficiently representative of governance and managerial tasks. To ascertain the governance bodies' degree of involvement in each task and to show who has decision-making power in the different functions, two indicators were calculated. On the one hand, "\% involvement" shows, for each governance body, the percentage of the sample companies in which that body was said to play one or more of the four proposed roles; it indicates each governance body's degree of involvement in each function. In order to determine the decision-making power, the Decide and Approve answers were combined in a single variable, "\% decision", which represents each body's decision-making capacity. The following table shows these indicators for each function. 
Table 3.4 Involvement and decision level of governance bodies

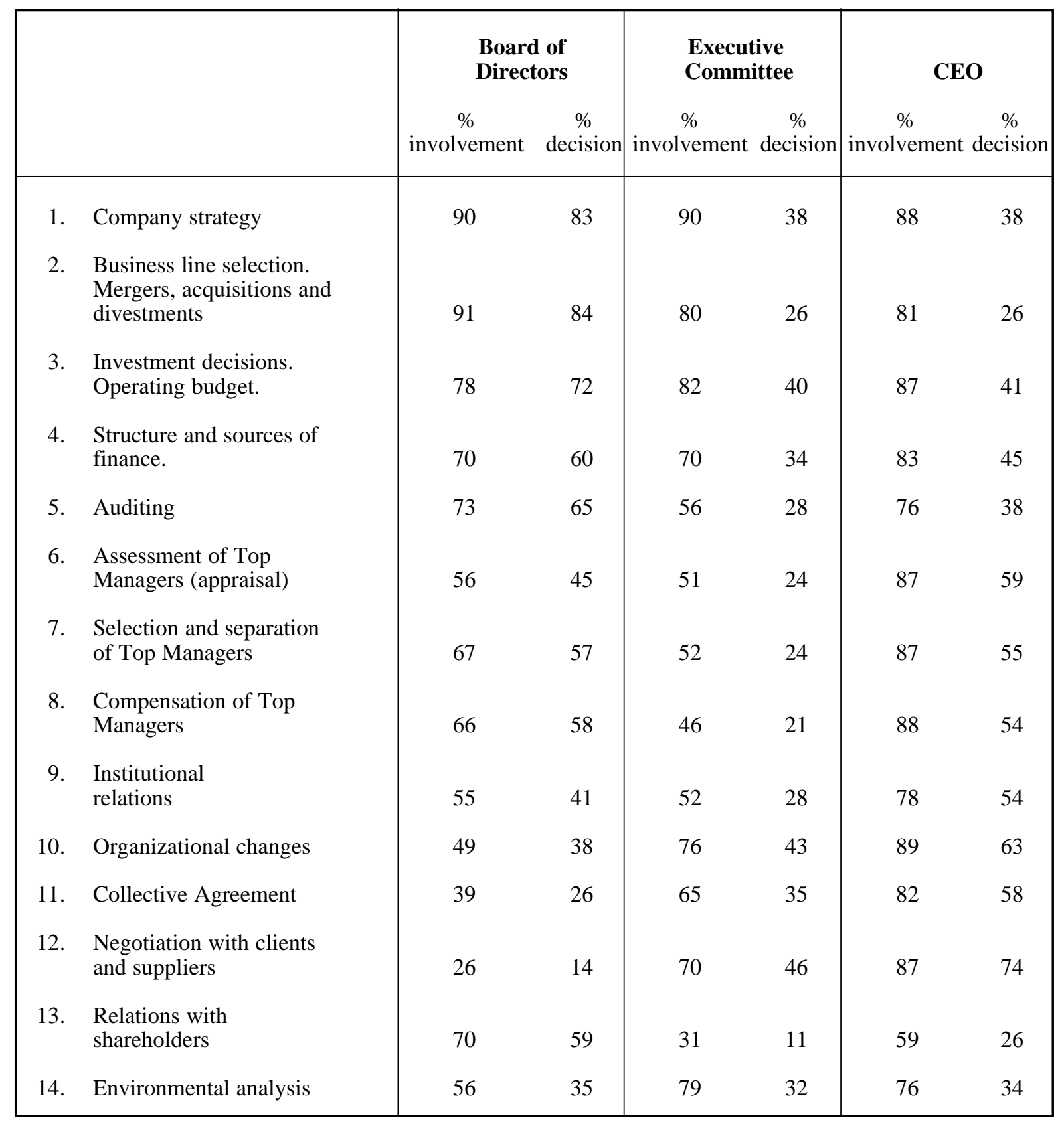

Analysis of these results allows us to affirm that it is normal practice in Spanish companies for Boards of Directors to play a significant role in strategy decisions (83\% decide), business selection (84\%), investment decisions (72\%), auditing (65\%), defining the financial structure and sources of finance $(60 \%)$, and relations with shareholders $(59 \%)$. The CEO, in contrast, is particularly strong on basically managerial functions: negotiations with clients and suppliers (74\%), organizational changes (63\%), and collective agreements (58\%). The CEO has much the same $\%$ of decision as the Board of Directors in the appraisal, recruitment and compensation of top managers. The role of the Executive Committee emerges as secondary; it does not have a predominant position in any function. 
If we look at "\% involvement", we see that the Board of Directors plays a greater role than the other bodies only in relations with shareholders, strategy decisions, business selection, and mergers, acquisitions and divestments. It plays a greater role than the Executive Committee in decisions that affect managers (although it is the CEO who actually makes the decisions in most cases) and in auditing. These are all indications of the Board of Directors' strategic (decision) and supervisory (involvement) role.

Perhaps the most noteworthy finding from the above table is the exclusion of the Board of Directors from some basic decisions. For instance, the "\% decision" of the Board of Directors in the appraisal, recruitment and compensation of top managers is relatively low, slightly above $50 \%$. And yet, nurturing the development of top executives is one of the Board of Directors' main responsibilities. The fact that $35 \%$ of the Boards of Directors do not decide in auditing, one of the tasks most stressed by the Cadbury Report, also needs to be highlighted. Even more important is the fact that $61 \%$ of the Boards do not take part in negotiating the collective agreement, a vital issue in a country like Spain. The Board's involvement and decision power in organizational issues is also very low.

Table 3.5 shows the "\% decision" of the different governance bodies in companies with active Boards and in companies with non-active Boards.

Table 3.5 Decision level of different governance bodies depending on the Board's activity

\begin{tabular}{|c|c|c|c|c|c|c|c|}
\hline & & \multicolumn{2}{|c|}{$\begin{array}{c}\text { Board of Directors } \\
\% \text { decision }\end{array}$} & \multicolumn{2}{|c|}{$\begin{array}{l}\text { Executive } \\
\text { Committee } \\
\% \text { decision }\end{array}$} & \multicolumn{2}{|c|}{$\begin{array}{c}\text { CEO } \\
\% \text { decision }\end{array}$} \\
\hline & & $\begin{array}{l}\text { Active } \\
\text { Boards }\end{array}$ & $\begin{array}{l}\text { Non-active } \\
\text { Boards }\end{array}$ & $\begin{array}{l}\text { Active } \\
\text { Boards }\end{array}$ & $\begin{array}{l}\text { Non-active } \\
\text { Boards }\end{array}$ & $\begin{array}{l}\text { Active } \\
\text { Boards }\end{array}$ & $\begin{array}{c}\text { Non-active } \\
\text { Boards }\end{array}$ \\
\hline & Company strategy & 91 & 66 & 35 & 43 & 32 & 46 \\
\hline & $\begin{array}{l}\text { Business line selection. } \\
\text { Mergers, acquisitions and } \\
\text { sales }\end{array}$ & 89 & 74 & 27 & 27 & 24 & 30 \\
\hline & $\begin{array}{l}\text { Investment decisions. } \\
\text { Operating budget }\end{array}$ & 79 & 60 & 40 & 40 & 38 & 46 \\
\hline & $\begin{array}{l}\text { Structure and sources of } \\
\text { finance }\end{array}$ & 64 & 53 & 33 & 40 & 41 & 52 \\
\hline & Auditing & 67 & 58 & 27 & 28 & 37 & 40 \\
\hline & $\begin{array}{l}\text { Assessment of Top } \\
\text { Managers (appraisal) }\end{array}$ & 50 & 36 & 22 & 27 & 54 & 66 \\
\hline & $\begin{array}{l}\text { Selection and separation of } \\
\text { Top Managers }\end{array}$ & 67 & 39 & 23 & 23 & 48 & 64 \\
\hline & $\begin{array}{l}\text { Compensation of Top } \\
\text { Managers }\end{array}$ & 63 & 49 & 19 & 23 & 51 & 58 \\
\hline & Institutional relations & 48 & 28 & 31 & 28 & 52 & 57 \\
\hline & Organizational changes & 44 & 28 & 42 & 43 & 60 & 67 \\
\hline & Collective Agreement & 33 & 16 & 34 & 35 & 57 & 62 \\
\hline & $\begin{array}{l}\text { Negotiation with clients } \\
\text { and suppliers }\end{array}$ & 18 & 5 & 47 & 46 & 73 & 74 \\
\hline & $\begin{array}{l}\text { Relations with } \\
\text { shareholders }\end{array}$ & 63 & 53 & 12 & 11 & 25 & 26 \\
\hline & Environmental analysis & 40 & 22 & 32 & 32 & 29 & 41 \\
\hline
\end{tabular}


The decision-making power of non-active Boards of Directors is significantly smaller than that of active Boards. Looking at the other governance bodies, we can see that the CEO is the one who assumes power when the Board is non-active. Obviously, the causal relation may be the reverse, i.e. it may be that the Board becomes non-active because a powerful CEO does not let it act.

We can also see that although active Boards of Directors have greater decisionmaking power in all the functions, there are still some functions in which their power remains very low: auditing, organizational changes, collective agreement, and managing top managers.

All of this can help to better understand the differences between active and nonactive Boards of Directors. There is a group of activities in which the decrease in decision power from active to non-active Boards translates into greater decision power for the CEO (environmental analysis, strategy, appraisal and recruitment of top managers). This means that in relation to these important decisions, there is a balance of power between the Board and the CEO. When the Board is less active, the CEO takes on a more prominent role to compensate for the lack of effective governance.

There is another group of activities (institutional relations, collective agreement, organizational changes, and negotiations with clients and suppliers) where the decrease in decision power from active to non-active Boards is not offset by an increase in CEO decision power. In this case, therefore, given the nature of the decisions concerned, which are much more to do with management than with governance, one can conclude that some active Boards may be taking on too many managerial functions (thus interfering with the CEO's role).

Even non-active Boards have very considerable decision power in some of the functions, specially the strategic ones. There are at least two possible explanations: although the Board of Directors does not develop all its operating potential, it may be that it vetoes the CEO's decisions; alternatively, it may be that the Board of Directors decides or approves what has in fact already been decided or approved by the CEO or Executive Committee. The next section may shed additional light on these issues.

Let us look at all of these data in graphic form. Multivariate factorial analysis has been used. Due to the high correlation of the different governance bodies in many of the functions, we can represent their behaviors with two factors, which we have plotted on a twodimensional plane. The following graphs show the positioning of the governance bodies and of the functions when the Board of Directors is active (Figure 3.3) and when it is non-active (Figure 3.4). As an intuitive idea, this technique enables functions that have similar behaviors to be plotted close together and those that are different to be plotted distant from each other. 
Figure 3.3. Factor analysis for companies with active Boards

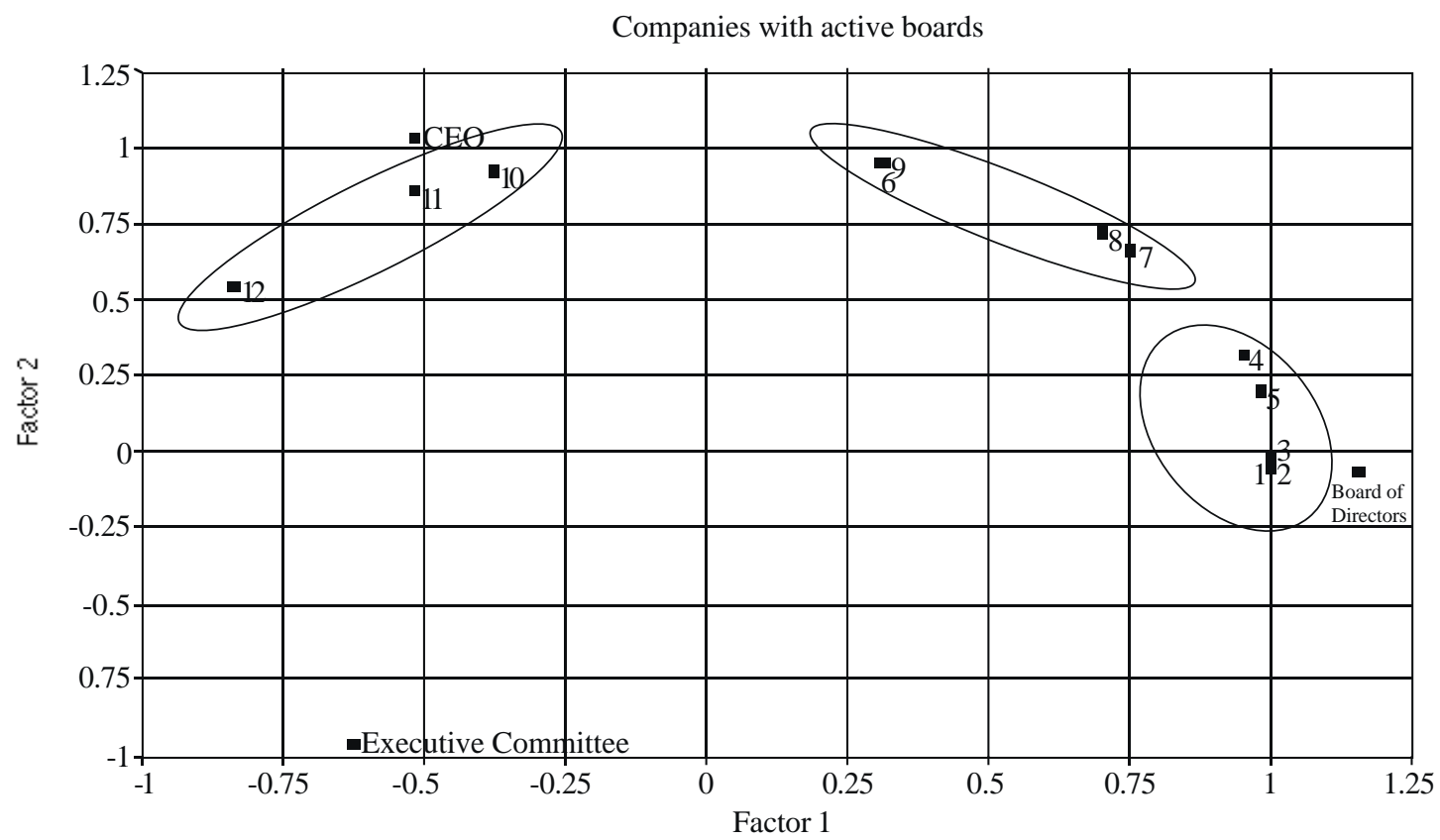

Figure 3.4. Factor analysis for companies with non-active Boards

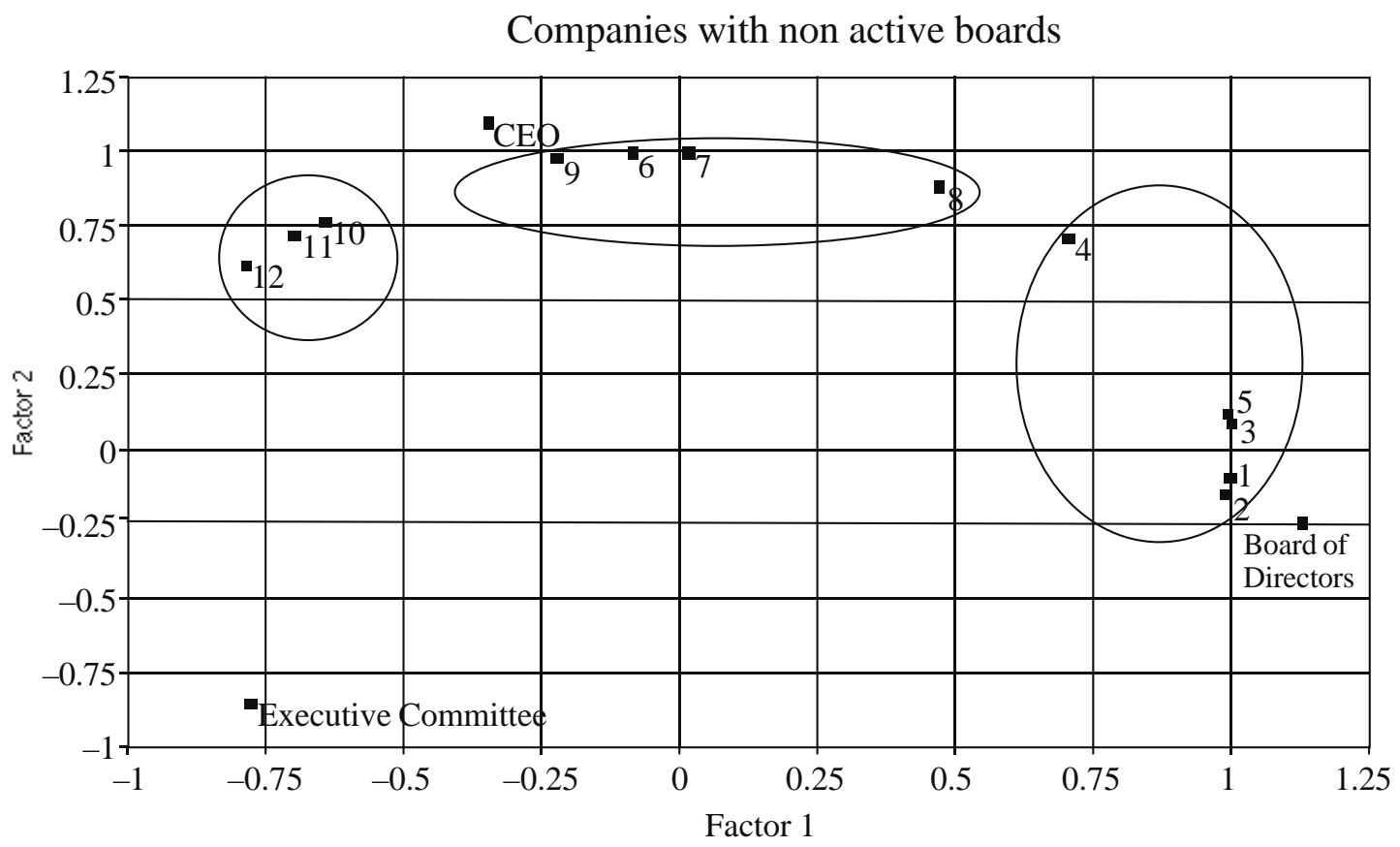

In these graphs we did not plot the "environmental analysis" and "relations with shareholders" variables, as both have a special behavior. 
We can see that there are three groups of functions:

Functions taken on by the Board of Directors, even by non-active Boards. These are basically strategic decisions, again showing the important role played by the Board in strategic issues. The functions are:

1. Company strategy.

2. Selection of business lines. Mergers, acquisitions and sales.

3. Investment decisions. Operating budget.

4. Establishment of financial structure and sources of financing.

5. Audits.

Functions shared between the Board of Directors and the CEO. These correspond basically to the task of managing top managers. Here, active Boards play an important role, while non-active Boards "delegate" to the CEO. One essential difference, therefore, between active and non-active Boards is their involvement in the development of the top management team. The functions are:

6. Assessment of top managers (appraisal).

7. Separation and selection of top managers.

8. Compensation of top managers

9. Institutional relations.

Functions taken on by the CEO. This group comprises the more executive and managerial decisions, basically made by the CEO, even when there is an active Board. The functions are:

10. Organizational changes.

11. Collective agreement

12. Negotiations with clients and suppliers.

This tentative analysis shows us how important it is to understand the balance of power between the CEO and the Board in order to gain an insight into the contribution each one makes and the role each plays in practice. An analysis of each in isolation is not enough. We shall therefore explore this balance of power in greater depth in the following section.

\section{The relative power of CEOs and Boards of Directors as a classification scheme}

In the previous section, we studied some descriptive characteristics of the different governance bodies and took a first step towards understanding the relative power of these bodies. This understanding is vital, specially in view of the overall push, both by academics and by practitioners, towards a revitalization of the Board of Directors. Many of the suggestions for reforming corporate Boards are aimed at strengthening the Board's power relative to that of the CEO.

Pearce and Zahra (1991) studied the Board-CEO relationship using data collected from Fortune 500 Industrial and Fortune 500 Service corporations. They used the two by two typology shown in Figure 4.1 below. 
Figure 4.1: Typology of Boards of Directors

Source: Pearce and Zahra (1991)

\begin{tabular}{|c|c|c|}
\hline & Boa & High \\
\hline & Statutory & Participative \\
\hline High & Advisory (Vance, 1968) & Collegial (Vance, 1968) \\
\hline & Statutory (Aram and Cowen, 1983) & Shared Leadership (Hermann, 1987) \\
\hline & Managerial Control (Molz, 1985) & Participative (Wood, 1983) \\
\hline CEO & Ratifying (Wood, 1983) & Normative/Strategic (Molz, 1985) \\
\hline & Caretaker & Proactive \\
\hline Low & $\begin{array}{l}\text { Third Party (Hermann, 1987) } \\
\text { Review \& Approve (Molz, 1985) }\end{array}$ & $\begin{array}{l}\text { Proactive (Hermann, 1987) } \\
\text { Strategic/Shareholders' Control (Molz, 1985) }\end{array}$ \\
\hline
\end{tabular}

The characteristics of each of these types of Boards of Directors are as follows:

Caretaker: The main characteristic of this type of Board is the lack of power of both the $\mathrm{CEO}$ and the Board. Here, the Board is normally regarded merely as a legal obligation to safeguard the shareholders' wealth, and has little real capacity to influence decision-making. Power in the organization is diluted between the CEO and other top managers. Accordingly, there is no real governance body.

Statutory: Characterized by a weak Board of Directors and a powerful CEO. The Board is ineffectual, its sole function being to confirm the chief executive's decisions. Board members are chosen by the CEO and make little effort to define their role and functions, confining themselves to ceremonial approvals that legitimize the CEO's power.

Proactive: Characterized by a weak CEO and a powerful Board. Two types can be distinguished: first, those that work in favor of the company, and second, those that serve their own interests. This type of Board can normally be transformed into an effective weapon for activism by shareholders concerned about the company's management or their own interests. Sometimes, a proactive Board can take on an excessively prominent role in management, even to the point of replacing the CEO.

Participative: Characterized by a powerful CEO and a powerful Board of Directors. This type of Board is characterized by a high degree of debate, discussion and even discord between the CEO and the Board. Leadership of the company is shared. As both have more or less equal power, most decisions must be taken by consensus; and many vehicles of negotiation are established, as neither has formal mechanisms to prevail on its own.

Pearce and Zahra (1991) classified the companies in their sample according to the relative authority of Board and CEO in relation to 15 major types of decisions, ranging from approving changes in capital structure to selecting the new CEO. They then studied the differences among these four groups in terms of the characteristics, composition, internal process, decision-making style and effectiveness of the Board, as well as in terms of 
organizational performance. They found significant differences among the four types of Board with regard to characteristics (independence, expertise, involvement), process and style. The only relevant difference in composition was female representation. Finally, participative Boards were associated with the highest level of company financial performance.

These are interesting insights and we used the data obtained from our questionnaire to replicate this analysis for the Spanish data. We have used a different set of decision variables (described in the previous section), but it remains close enough to the one used by Pearce and Zahra. We have used a different set of variables to study characteristics, compensation, and process and style. These variables are:

Characteristics

Level of activity (active vs. non-active)

Executive Committee (Yes or No)

Who appoints the directors (Board, CEO, shareholders)

Composition

Size of the Board (number of directors on the Board)

Type of directors on the Board (insiders vs. outsiders)

Process and style

Frequency of meetings (number of meetings per year)

Duration of meetings (hours spent in each meeting)

To establish the different types of Boards of Directors, the companies were classified according to the answers they gave regarding the role of each governance body in the 14 key functions (question no. 18).

In order to decide to which of the four types (caretaker, statutory, proactive, participative) the Board of Directors of each company in our sample belonged, we proceeded as follows. We calculated the power of the CEO and the power of the Board by counting up the number of functions in which each was said to decide or approve decisions. This gave us two scores between 0-14. These scores showed, up to a point, the decision power of the Board of Directors and the CEO in the 14 executive functions. Next, the Board of Directors or CEO were considered to have a "high" decision power if the number of issues on which they decided or approved decisions was equal to or greater than 8, and a "low" decision power if the number was equal to or less than 5. Companies with a value of 6 or 7 were excluded in order to increase the discriminating power among the resulting groups. This process made it possible to classify the companies on the basis of the above characteristics (see Figure 4.2). 
Figure 4.2. Classification of the companies according to CEO and Board decision power

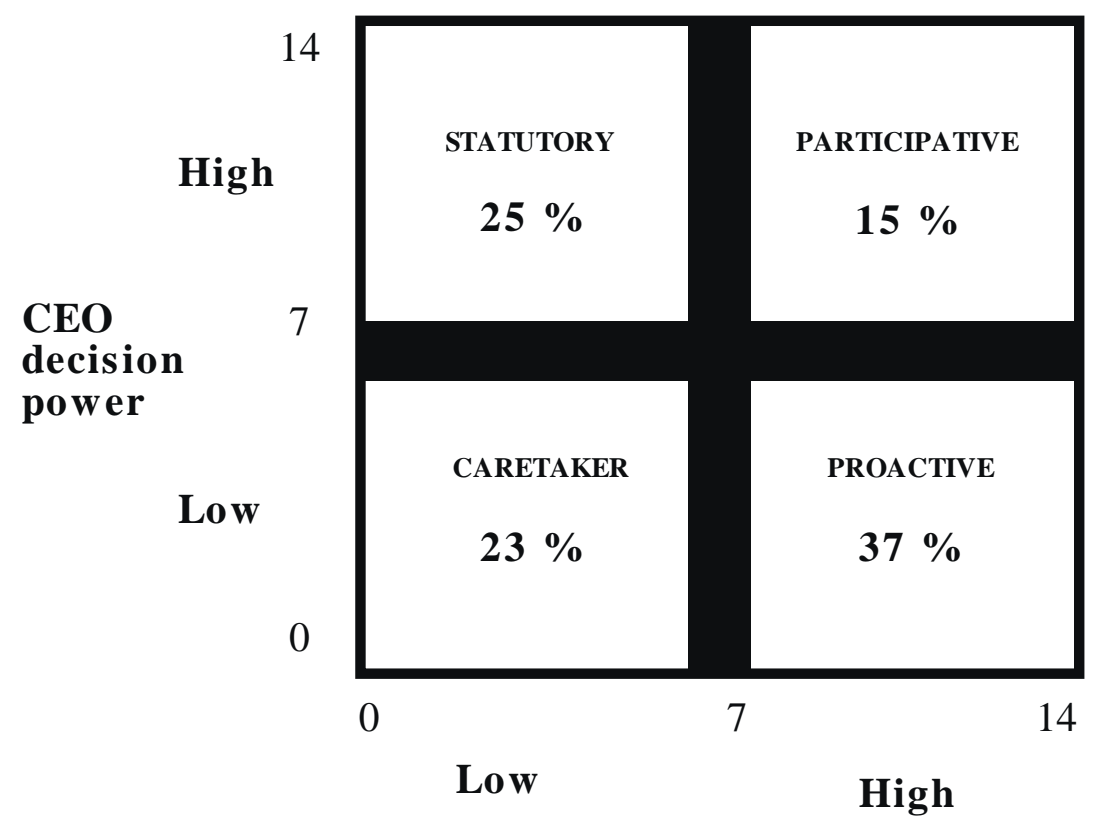

Board decision power

Of the 498 companies in the sample, 280 were classified. The results of the classification showed the following distribution: $37 \%$ of the companies had proactive Boards, and $23 \%$ of the Boards were caretaker. In cases where the CEO had "high" decision power, it was observed that $25 \%$ had statutory Boards, and $15 \%$ of the Boards were participative, i.e. showing a balance of power between Board of Directors and CEO.

\section{Hypotheses}

\section{Performance}

In agreement with Pearce and Zahra (1991) and bearing in mind the limitations of the performance data in our questionnaire, we propose two hypotheses:

H1. Companies with participative Boards of Directors are more profitable.

H2. Companies with participative Boards of Directors are more productive.

\section{Characteristics}

In this part we have used three variables relating to Board activity, the existence of an Executive Committee, and the appointment of new directors. With regard to Board activity, we can assume that a powerful Board will have a higher level of activity.

H3. Strong (proactive and participative) Boards are more active than weak Boards. 
With regard to the existence of an Executive Committee, taking the EC to be a body that helps govern the company, we may assume that the percentage of companies with an EC will be greater among companies in which there is a balance between CEO and Board. If both CEO and Board are powerful, the EC will play a supporting role. And if both CEO and Board are weak, the EC will play a leading role in governing the company.

H4. The balance of power between CEO and Board tends to strengthen the need for an Executive Committee.

Firms with statutory Boards are characterized by having a weak Board and a strong CEO. Therefore:

H5. The percentage of directors appointed by the CEO is higher in companies with statutory Boards.

\section{Composition}

Here, we used two variables: size, and percentage of outside directors. We make no hypothesis about a relationship between size and type of Board, but we do hypothesize a greater percentage of outsiders in participative Boards, in accordance with Pearce and Zahra (1991). Therefore:

H6. Participative Boards have a higher percentage of outside directors.

\section{Process and Style} Boards.

Powerful Boards are likely to meet more often and for longer than ineffectual

H7. Powerful (participative and proactive) Boards meet more often and for longer.

\section{Type of Ownership and Size}

We were also interested in studying the distribution of the different types of Boards in each type of ownership. One might expect to find some regularities that could be of interest. Finally, we also studied the size of each group of companies. Both can be considered control variables and may help to account for the results we obtained.

\section{Results}

\section{Performance}

As shown in Table 4.1, we found no statistically significant differences in terms of profitability. However, average profitability in our sample is slightly higher in companies with weak CEOs than in companies with strong CEOs.

Nor did we find significant differences in productivity, calculated in terms of sales per employee. However, the productivity of firms with participative Boards is twice that of 
the other types of firms. In spite of being so large, this difference is not statistically significant (95\%), owing to the high variance of productivity in companies with participative Boards.

At this point, it is worth recalling one of the objections to the questionnaire raised earlier: it is not very realistic to measure the profitability or productivity of governance practices using the results of just one year. All governance practices take time to produce results. Therefore, it is not surprising that we should have been unable to prove any relationship between practices and performance, especially considering the way these practices are changing in Spain.

Table 4.1. Performance and Board typology

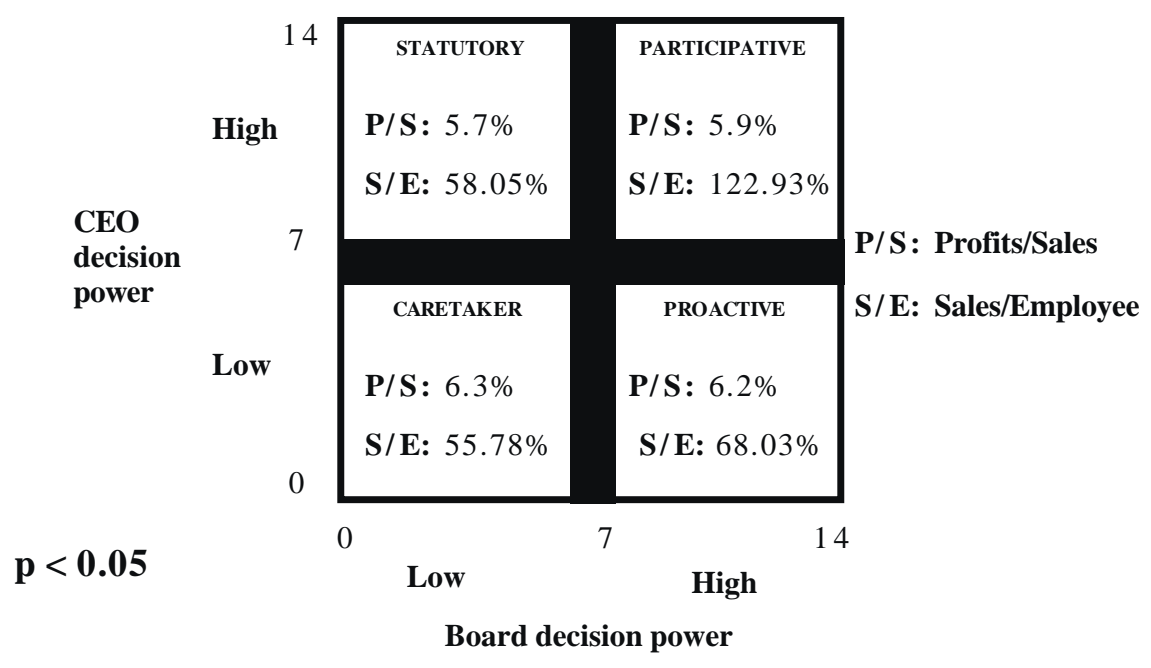

\section{Characteristics}

We can see from Table 4.2 that we can accept hypotheses 3 and 4 . The companies with strong (participative and proactive) Boards do indeed have a higher level of active Boards. We can also see that in companies where there is a balance of power between the CEO and the Board (participative and caretaker), the percentage of ECs is higher. Where there is a participative Board, there is an EC supporting the CEO. In the case of caretaker Boards, where the CEO and the Board have no power, the EC is the body that really manages the company.

Table 4.2. Characteristics and Board typology

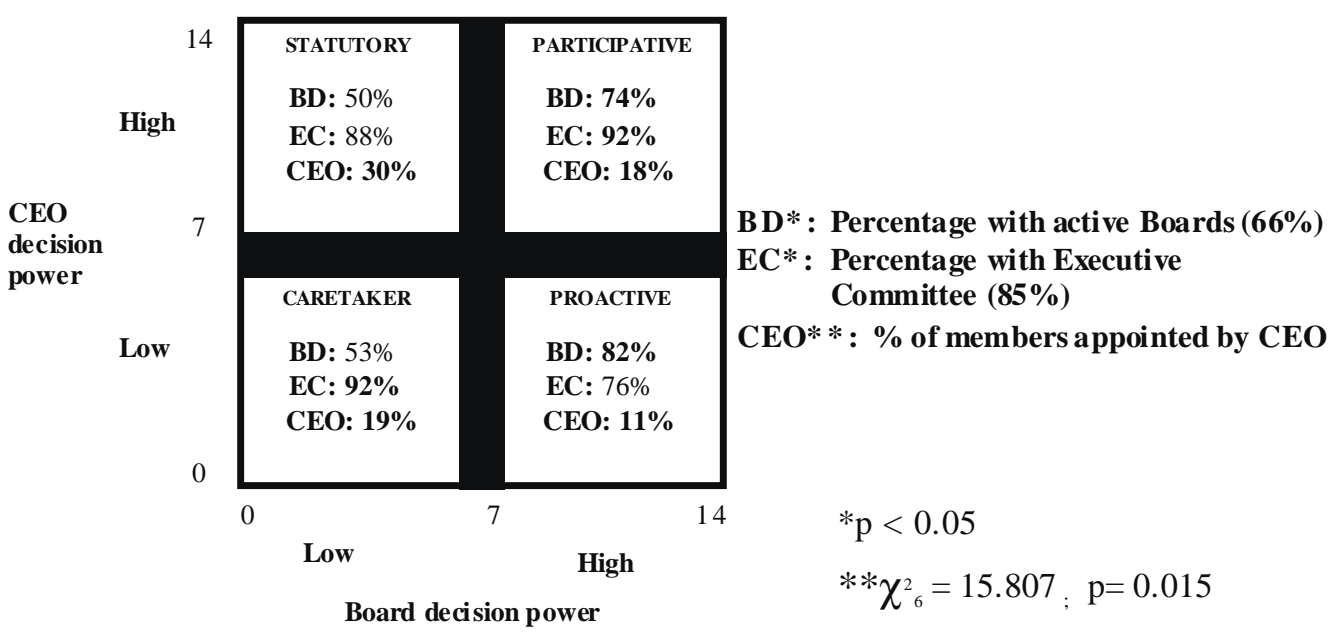


The results of our analysis of the CEO's influence on the appointment of new Board members show that such appointments are not independent of the type of Board of Directors. Specifically, the CEO's influence is greater in companies with statutory Boards (30\%) than in the others. This confirms the idea that ineffectual Boards of Directors are made up of people picked by the most powerful person in the company, be this the Chairman or the CEO. Thus, hypothesis 5 -which states that the CEO's influence in appointing new Board members will be greater in companies with statutory Boards of Directors-, can be accepted.

\section{Composition}

When considering the composition of the Board of Directors, we should study basically the size of the Board and the number of inside and outside directors. Table 4.3 shows the composition of the different types of Boards in these terms. The most salient comparison is without doubt that between companies whose CEO has a higher level of power and those where the CEO has less power. The former are the statutory and participative Boards. They have a very similar composition: about $65 \%$ outsiders and $35 \%$ insiders. The distribution of outsiders and insiders is more even in the other two types of Boards. In caretaker Boards, the proportion is $50 \%$, while in proactive Boards there is a higher percentage of outsiders $(57 \%)$.

Table 4.3. Composition and Board typology

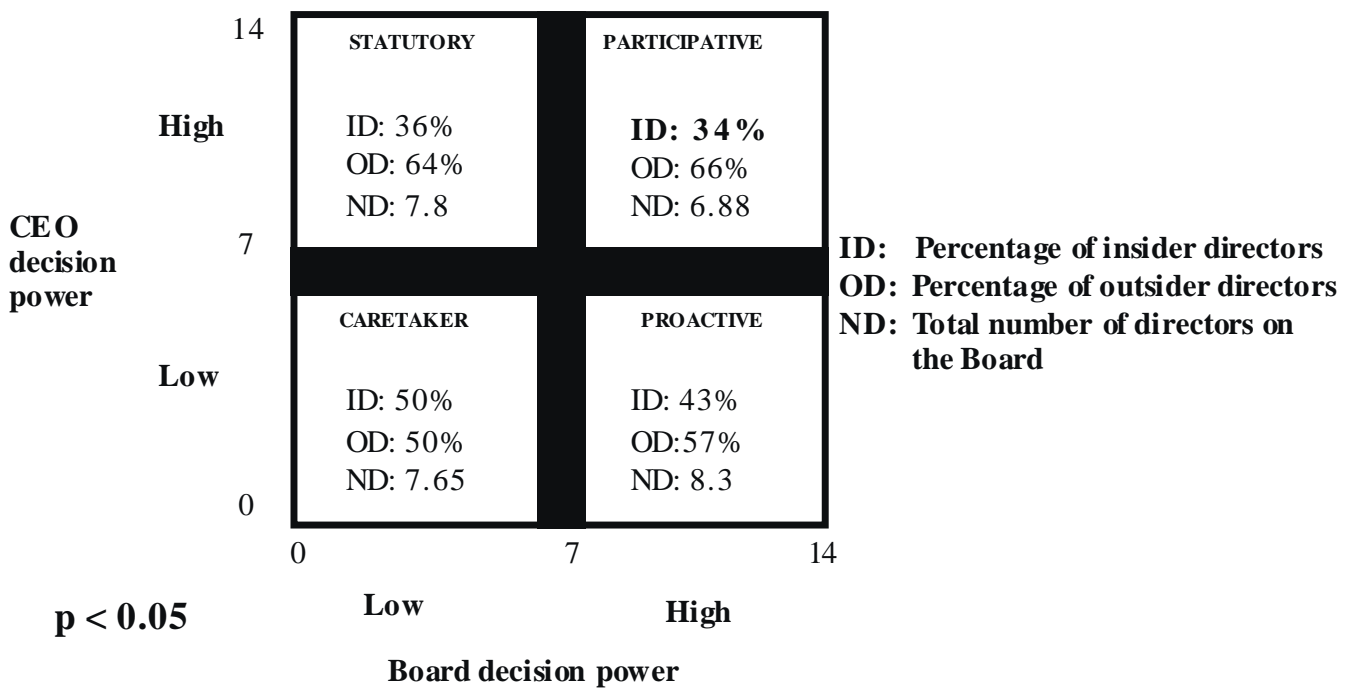

Proactive Boards are the largest. Participative Boards are the smallest, but they have the highest proportion of outside directors (66\%). The size of the Board may be related to the size of the company, but it is also true that smaller Boards, with about 7 directors, are very good for team work and effective governance. When CEOs want ineffectual Boards, they tend to make them very large. Thus, hypothesis 6 can be accepted. 
The high percentage of outside members in statutory Boards helps us appreciate that the numbers of outsiders is not related to effective governance (Dalton et al., 1998). We need to consider other characteristics of the Board.

\section{Process and style}

As can be seen in Table 4.4, Proactive Boards have more meetings, with an average of 10 per year. Participative Boards meet 7 times a year, statutory Boards an average of 6 times a year, and caretaker Boards 5.65 times a year (the data show 90\% confidence). For a caretaker Board to "take care" of the company, it is sufficient for it to study the auditors' report and approve the budget; consequently, 3 or 4 meetings a year are enough.

Statutory Boards are different. The number of times they meet is irrelevant: ultimately, what the CEO says is what is done. In contrast, Boards that monitor the company closely (participative and proactive Boards) require more meetings. Thus, we can accept hypothesis 7.

Table 4.4. Process and style and Board typology

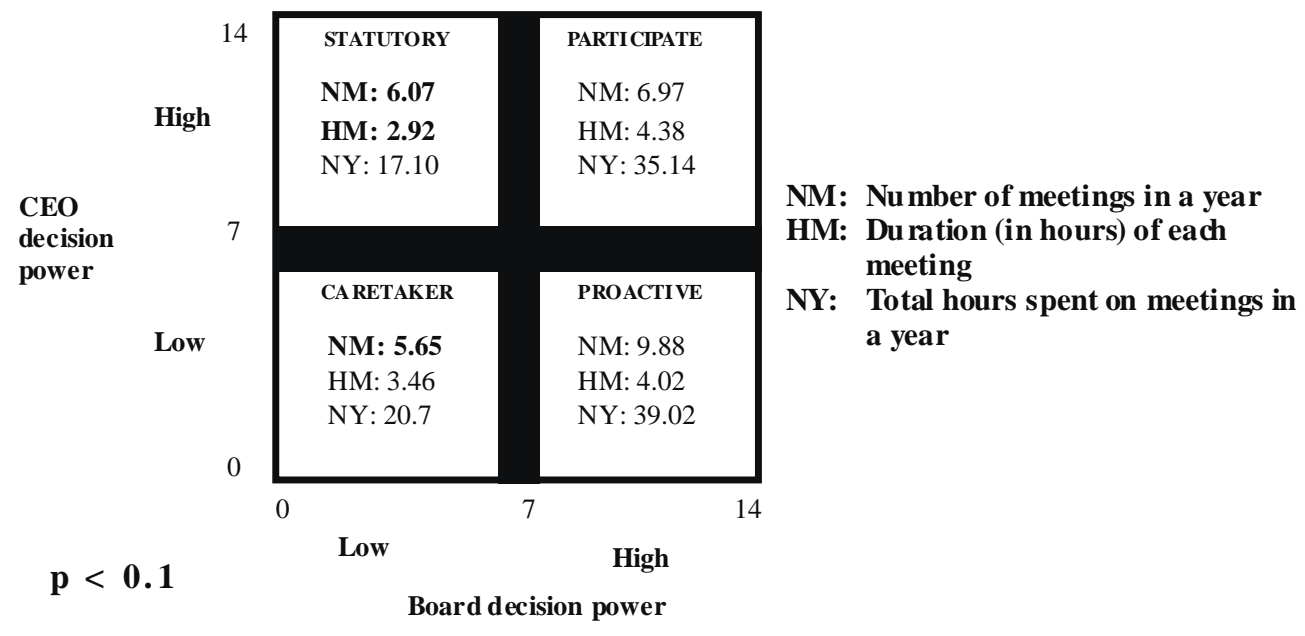

\section{Type of Ownership and Size}

We see that companies with participative Boards are smaller (in sales and employees) than the rest. This difference is statistically significant (95\%). 
Table 4.5. Size and Board typology

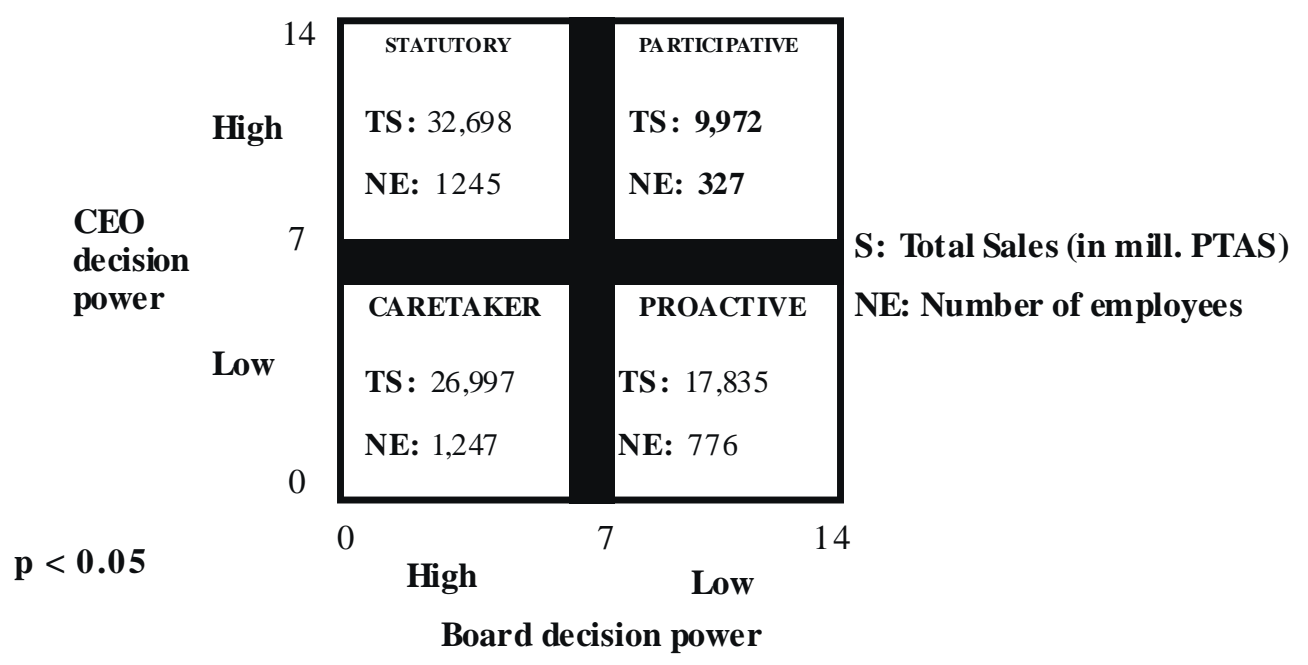

If we study the relationship between Board typology and type of ownership (Table 4.6), we see a higher percentage of proactive Boards among State-owned and non-family companies (about 40\%). Statutory Boards have a greater presence in State-owned and multinational companies (about 30\%).

Family businesses have a higher percentage of caretaker Boards (28\%), although the percentage of statutory Boards in this type of company is not far behind (26\%). This result is consistent with the model of a first or second-generation family business with a CEO-founder in the company's management. The percentage of participative Boards is smaller in Stateowned companies $(5 \%)$ than in the rest.

It is interesting to note that the percentage of powerful (proactive and participative) Boards is higher in non-family companies $(58 \%)$ than in the rest. If we look at the percentage of powerful CEOs (statutory and participative), they account for $47 \%$ of multinational firms, $40 \%$ of family businesses, $37 \%$ of State-owned companies, and $35 \%$ of non-family companies. This greater presence of powerful CEOs in multinational companies can be understood if we consider that the CEO in a subsidiary company is appointed to lead (we must remember that in these companies a larger proportion of Boards are formed for purely legal purposes). The same applies to many family businesses, where the CEO is the absolute boss. 
Table 4.6. Type of ownership and Board typology

\begin{tabular}{|l|c|c|c|c|c|}
\hline & Multinational & State-owned & Family & Non-family & TOTAL \\
\hline Proactive & $33 \%$ & $45 \%$ & $32 \%$ & $41 \%$ & $37 \%$ \\
\hline Caretaker & $21 \%$ & $18 \%$ & $28 \%$ & $23 \%$ & $23 \%$ \\
\hline Participative & $16 \%$ & $5 \%$ & $14 \%$ & $17 \%$ & $15 \%$ \\
\hline Statutory & $29 \%$ & $32 \%$ & $26 \%$ & $18 \%$ & $25 \%$ \\
\hline Total & $100 \%$ & $100 \%$ & $100 \%$ & $100 \%$ & $100 \%$ \\
\hline
\end{tabular}

$\chi^{2}{ }_{9}=7.451 ;$ df : $9 ; p=0.59$

\section{Discussion}

Our results are summarized in Table 4.7. Like Pearce and Zahra, we do find some significant differences among the four groups of Boards. Some differences in Board characteristics, Board composition and Board process are statistically significant. Also, companies with participative Boards are different in terms of size, and quite different in terms of Board attributes. Furthermore, participative Board practices are usually associated with good practices in the literature.

Unfortunately, our data do not allow us to prove any significant differences in performance (in spite of the almost double productivity of companies with participative Boards). We strongly believe that this lack of any positive association between participative Boards and performance is due to the high intersectorial variability of our data and the changes currently taking place in Spain in the area of corporate governance -changes whose effects will only become apparent in the future. One cannot relate governance practices to results when the practices are rapidly changing.

However, the differences in the attributes of participative Boards with respect to other types leads us to subscribe to Pearce and Zahra's view that "CEOs might generally be well advised to seek ways to share power with directors in an effort to achieve more favorable financial performance". 
Table 4.7. Conclusions

\begin{tabular}{|l|l|l|}
\hline & \multicolumn{1}{|c|}{ Hypothesis } & Conclusion \\
\hline Performance & H1. $\begin{array}{l}\text { Companies with participative Boards of } \\
\text { Directors are more profitable. } \\
\text { H2. } \begin{array}{l}\text { Companies with participative Boards of } \\
\text { Directors are more productive. }\end{array}\end{array}$ & $\begin{array}{l}\text { Not } \\
\text { proven }\end{array}$ \\
\hline Characteristics & H3. $\begin{array}{l}\text { Strong (proactive and participative) Boards } \\
\text { are more active than weak Boards. } \\
\text { proven }\end{array}$ & Proven \\
\hline $\begin{array}{l}\text { The balance of power between CEO and } \\
\text { Executive Committee. }\end{array}$ & Proven \\
\hline Composition & H6. $\begin{array}{l}\text { The percentage of members appointed by the CEO } \\
\text { is higher in statutory Boards. } \\
\text { percentage of outsiders. }\end{array}$ & Proven \\
\hline $\begin{array}{l}\text { Process and } \\
\text { Style }\end{array}$ & H7. $\begin{array}{l}\text { Powerful (participative and proactive) Boards } \\
\text { meet more often and for longer. }\end{array}$ & Proven \\
\hline
\end{tabular}

\section{The Board's role in managing top managers}

In this section, we wish to explore in greater depth one of the fundamental tasks associated with corporate governance: management appraisal and compensation. We have already seen that these types of functions are not well covered by Boards in Spain. In this section, we will study the practices adopted in reality, and their main determinants.

This section is divided into two parts. In the first part, we will describe existing appraisal practices and compare them with the practices followed in the USA. In the second part, we will study the determinants of CEO compensation and how it relates to Board practices.

\section{Appraisal}

The most traditional and best-known personnel appraisal systems originated in the United States as a consequence of US legal requirements: a series of lawsuits over discriminatory work efficiency appraisals generated a body of legislation. In 1978 the United States Congress approved the Civil Service Reform Act, which established the need for formal appraisal systems for most federal agencies. In 1992, in a survey of private Fortune 100 companies, it was shown that $95 \%$ of them had a formal personnel appraisal system (Wilson, 1995). In another survey, conducted in 1996 and answered by 756 North American 
There are also differences by type of structure. Only $34 \%$ of the companies with a functional organization have formal appraisal systems, whereas in companies with more complex and differentiated structures the figure is $60 \%$.

As we have said before, there is a link between type of ownership and organizational structure: family businesses are more likely to adopt a functional structure, while multinational and non-family businesses are more likely to have a divisional or matrix structure. Greater structural complexity requires a greater degree of systematization in the guidance given to managers, or the use of integration mechanisms such as appraisal systems.

Size also plays a role in the adoption of formal appraisal systems. Close to $60 \%$ of the companies in our sample with more than 500 employees or turnover above 10,000 million pesetas have a formal system, while among those with a turnover under 5,000 million or under 200 employees fewer than $40 \%$ have one.

Nevertheless, for all company sizes in our sample, the use of formal systems can be considered as very low. Sometimes, specially in small companies, managers argue that formal systems are not needed because they know each other and perform appraisals on a daily basis. We believe this argument is mistaken.

First, a regular, written, formal system always affords greater protection against arbitrariness and discrimination, which are more common in small organizations where there are more power differences. Second, daily assessments are necessary but they are not enough; the attention and concentration that a regular, written system requires complements daily assessment and employee development. Finally, an informal system cannot provide the same commitment and rigor as a written system.

There are several empirical works about the positive impact of performance appraisals in improving a company's financial results, although none of them is absolutely conclusive. The results of this study suggest that companies which use formal appraisal systems are more profitable than those that do not (6.4\% vs. $5.0 \%)(1)$. If we analyze by type of ownership, we find that the differences are significant in State-owned and non-family companies, while in family businesses and multinational firms the impact of the management appraisal system is not significant.

(1) $\mathrm{p}<0.05$ 
Table 5.2 Profitability comparison between companies with and without formal appraisal systems

\begin{tabular}{|l|c|c|}
\hline \multicolumn{3}{|c|}{ Profits / Sales ratio } \\
\hline & $\begin{array}{c}\text { Companies } \\
\text { with formal systems }\end{array}$ & $\begin{array}{c}\text { Companies without } \\
\text { formal systems }\end{array}$ \\
MULTINATIONAL & $5.26 \%$ & $4.5 \%$ \\
STATE-OWNED & $\mathbf{1 0 . 2 2 \%}$ & $\mathbf{- 1 . 4 \%}$ \\
FAMILY & $5 \%$ & $6.2 \%$ \\
NON-FAMILY & $\mathbf{7 . 9 \%}$ & $\mathbf{5 . 0 \%}$ \\
TOTAL & $\mathbf{6 . 4 \%}$ & $\mathbf{5 . 0 \%}$ \\
\hline
\end{tabular}

One important aspect of the assessment process is deciding who should be included in it. Latham and Wixley (1993) study characteristics, advantages and disadvantages of the more common practices, as we discuss below.

The most common practice is appraisal by the immediate superior. This has some advantages in hierarchical organizations because the superior is responsible for the subordinates' development and compensation. As a consequence, he/she has the knowledge and motivation to carry out the appraisal. However, experience shows that appraisals tend to be biased by the way the superior would have done the job him/herself, or to be based just on results.

Other less standard practices are rapidly gaining in popularity in the US. One of them is peer appraisal. This was still rare in the '80s. Antonioni (1996) reports that $18 \%$ of US companies now use peer information in their appraisals. And the proportion is higher among the more advanced companies. Peer appraisal has many advantages. Peers tend to have better information and knowledge to carry out the appraisal, as well as a clear vision of the task performed by the appraised person. Furthermore, one can measure several parameters and obtain a more reliable estimation. However, it is advisable that this appraisal be carried out at the same time as the superior's appraisal, and it is very important that it be anonymous.

Another practice whose use is growing is subordinate appraisal. This kind of appraisal has certain advantages in common with peer appraisal and is an important source of feedback for management. Bernardin et al. (1993) indicate that subordinate appraisal is very important in relation to the way a superior manages and relates to subordinates, but should not include other managerial practices (such as budgeting or resource allocation), where subordinates do not have the criteria to make a judgment.

Finally, we are currently seeing the emergence of integrative systems such as 360 degree appraisals, which include all of the above together with the self-assessment of the appraised person. Usually, the superior uses all of this information to prepare the feedback 
interview. Companies like ATT, Bank of America, GE, Caterpillar, Chrysler, and others, use this system. An interview of 280 Mid-West companies revealed that $12 \%$ of them used $360^{\circ}$ appraisal. Even in Spain, some companies -such as AGF-Unión y el Fénix or Campofrío- are experimenting with it. Some researchers indicate that employees are reluctant to be appraised in this way if promotion decisions are at stake. However, $90 \%$ of the companies using it use it as a tool to decide wage increases, promotions and separations (Bohl, 1996).

Some procedural elements are very important. Information should be kept anonymous; evaluators should be selected by objective criteria; written feedback is essential. Antonioni (1996) reports that between $15 \%$ and $20 \%$ of managers get unexpected negative feedback. Therefore, feedback and associated action plans are fundamental.

Actual practices in Spain are far less advanced. As Figure 5.1 shows, most appraisals involve the immediate superior (79\%) and, to a much lesser degree, the CEO (49\%). The role of the Human Resources Manager is secondary (24\%). Only $12 \%$ of companies use two superiors. Finally, subordinate appraisal is used in only $4 \%$ of cases, a level corresponding to the last decade in the US. This seems to imply that we can expect to see rapid growth in this area in the near future.

Figure 5.1 Participants in manager appraisal

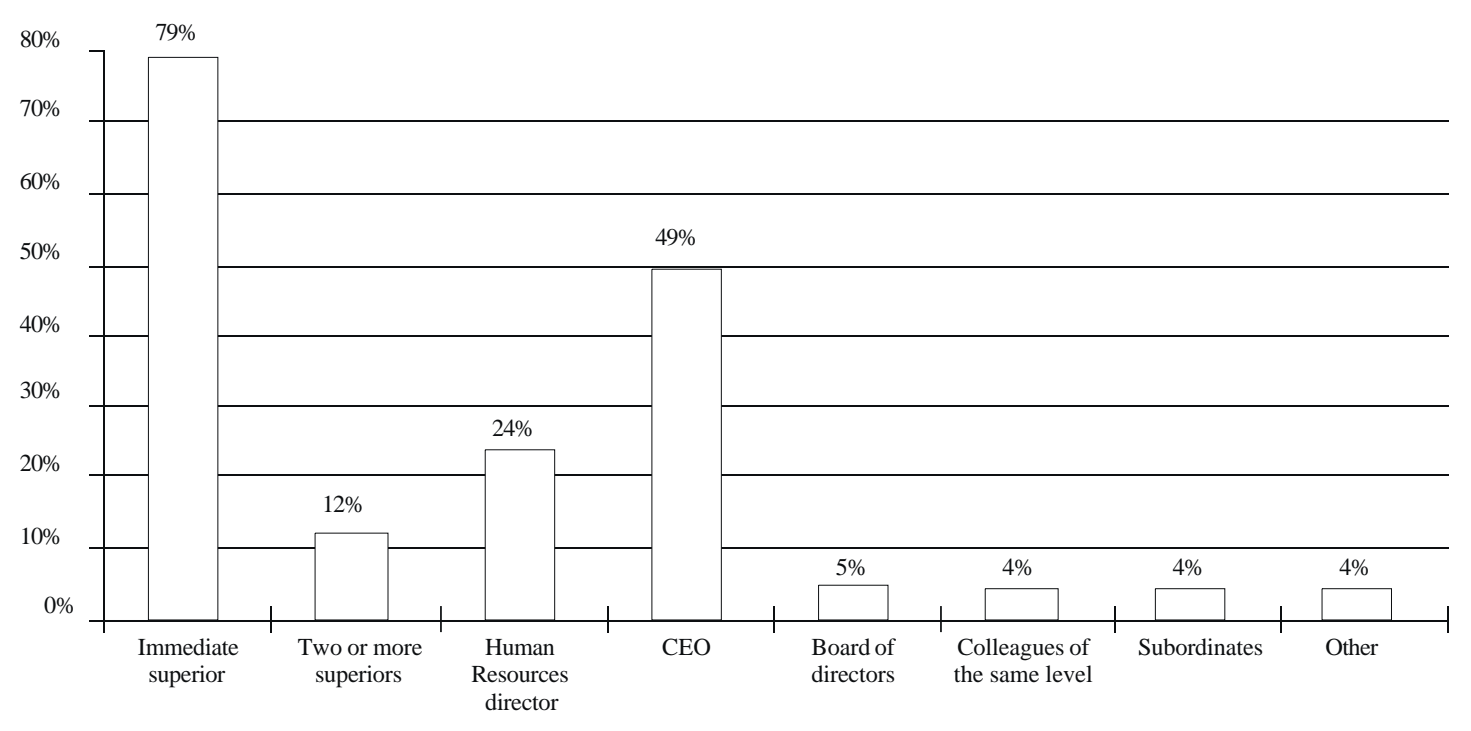

Some of the data on processes are very interesting. Most (80\%) of the companies that carry out appraisals do so once a year, $16 \%$ twice a year, and $4 \%$ more frequently. However, only $70 \%$ of the appraisals use formal documents and, more surprisingly, only $79 \%$ are discussed with the appraisee. $3.7 \%$ are sent to the person with no discussion and $17.5 \%$ are kept secret. One may wonder what the feedback effect of secret appraisals might be.

There is no doubt that appraisal systems have their critics (Ghorpade and Chen, 1995), who highlight the limitations of these systems. However, appraisal systems are of great help in managing managers and are an important governance tool. From our data, we can conclude that Spanish practices have a lot of room for improvement. The larger, more complex, more highly differentiated companies are the ones that are most likely to use formal systems and adopt more advanced practices. However, there is still a lot of catching-up to do. 


\section{Compensation (1)}

A very powerful governance mechanism is the way we compensate managers, particularly the CEO (Gómez-Mejía, 1994). In this section, we propose to study relevant aspects of Board behavior and the way they affect CEO compensation.

A recent survey by Towers Perrin in the US reported that $57 \%$ of management compensation was associated with results, while in 1989 the figure was only 37\% (Schmitt, 1996). Our Spanish data are very different. As Table 5.3 shows, the average variable compensation is only $19 \%$ for the highest level managers, decreasing to $13 \%$ for managers at the third level. These data reflect the low penetration of incentive pay in Spain.

Table 5.3 Percentage of fixed and variable compensation

\begin{tabular}{|l|c|c|}
\hline & \% fixed compensation & \% variable compensation \\
\hline Level I & $81 \%$ & $19 \%$ \\
Level II & $83 \%$ & $17 \%$ \\
Level III & $87 \%$ & $13 \%$ \\
\hline $\mathrm{p}<0.001$ & \multicolumn{2}{|c}{} \\
\hline
\end{tabular}

However, we believe that it is useful to study the determinants of incentive pay, as well as its association with corporate performance, using agency theory as a theoretical framework (Holmstrom, 1979).

The Board of Directors, as the representative of the shareholders, who are the owners, will be the "principal", and its goal will be to maximize its utility by maximizing the company's utility. The CEO will be the "agent"; his objective will be to maximize his utility by maximizing his expected remuneration, and his task will consist of managing the company in order to accomplish the shareholders' objectives.

To achieve their goals, the shareholders (represented on the Board of Directors) design a compensation and incentive system to align the CEO's goals with their own. The CEO's compensation will be made up of incentives based on his/her behavior, and incentives based on the outcome of his/her behavior.

In the case of CEO behavior-based incentives, the CEO will receive a fixed salary (Eisenhart, 1985, 1988) and, if appropriate, subjective variable incentives (Govindarajan and Gupta, 1985; Fisher and Govindarajan, 1993; Bushman et al., 1996).

The other alternative is compensation based on company outcomes. In this case, depending on the attainment of certain target indicators of company performance, the CEO will receive an objective variable incentive (Fisher and Govindarajan, 1993; Munter and Kren, 1995).

(1) This section is based mostly on Corrales (1998). 
In practice, contracts are usually a combination of these types of incentives: fixed salary, subjective variable salary and objective variable salary. The purpose of agency theory at this point is to determine the optimal combination of supervision- and outcome-based incentives.

\section{Hypothesis}

\section{Monitoring}

The Board of Directors could be an efficient tool for supervising the CEO. Improving the level of monitoring reduces the need for incentive pay and, therefore, reduces the risk shared by the agent and the associated agency cost (Eisenhardt, 1989; Munter and Kren, 1995). A greater number of outside directors will enable the Board to exercise closer supervision, and will therefore lead to a greater proportion of compensation being based on CEO behavior (Baysinger and Butler, 1985; Beatty and Zajac, 1994).

H1a. The proportion of outsiders on the Board is positively correlated with the proportion of behavior-based CEO incentive pay.

Another way to assess the level of Board supervision is through the level of Board activity in the company. The more active the Board, the greater its ability to assess the CEO's behavior and, therefore, the greater the proportion of behavior-based incentive compensation (Patton and Backer, 1987).

H1b. The Board's activity in governance decision-making is positively correlated with the proportion of behavior-based CEO incentive pay.

\section{Programmability}

The "programmability" of a task could be defined as the extent to which the activity a person carries out is predefined. The more operative the task to be done by the agent, the more programmable it is. The fact that an activity is more programmable directly affects the agent's monitorability, because it reduces the cost of information (Eisenhardt, 1985). Compensation will therefore be more behavior-dependent.

One of the organizational characteristics that could influence the programmability of the CEO's tasks is the type of activity the company is engaged in. Companies whose decision-making processes are more definable a priori will enable a higher level of programmability (Thompson, 1967; Fisher and Govindarajan, 1993). This is the case of primary production and manufacturing companies.

H2a. The proportion of behavior-based CEO incentive pay is higher in primary production and manufacturing companies.

Another organizational characteristic that should be taken into account is the level of decentralization or autonomy. According to Eisenhardt (1989), this variable affects a task's programmability. Greater decentralization, generally associated with divisional and matrix structures, is linked with a lower level of programmability in executive decisions. 
$\mathrm{H} 2 \mathrm{~b}$. The proportion of behavior-based CEO incentive pay is higher in companies with a functional structure.

Another organizational characteristic that affects the programmability of the CEO's tasks is company size. According to Eaton and Rosen (1983) and Holthausen and Larcker (1991), greater company size is associated with an increase in the difficulty and cost of monitoring. The larger the company, the more difficult it will be to obtain information to evaluate the efficiency of the decisions taken by the CEO.

$\mathrm{H} 2 \mathrm{c}$. The size of a company is negatively correlated with the proportion of behaviorbased CEO incentive pay.

\section{Ability to measure outcomes}

Holmstrom and Milgrom (1991) highlight the difficulty in associating good indicators with the behaviors we wish to induce. The agent will devote his efforts to tasks that are easier to measure and associate with a particular incentive. We also have to be alert to the CEO's ability to "manipulate" performance indicators.

Market ratios are usually considered better tools for evaluating CEO activity (Fama, 1980). Therefore, it will be easier to associate indicators with these measures. companies.

H3. The proportion of behavior-based CEO incentive pay will be smaller in listed

\section{Risk aversion}

In a family business, one may assume that the principal is more risk averse than in other types of business. This greater risk aversion should generate a tendency to compensate the CEO with a larger proportion of outcome-based compensation. companies.

H4. The proportion of behavior-based CEO incentive pay will be smaller in family

\section{Uncertainty about results}

Other factors that the CEO cannot control could affect the company's results. Uncertainty increases the risk premium of risk-averse agents and/or principals. Conversely, decreases in uncertainty should allow principals to define objectives better and should therefore be associated with a larger proportion of outcome-based compensation. Stateowned firms compete in regulated industries with lower competitive uncertainty (Ittner, Larcker and Rajan, 1997). Therefore:

H5. The proportion of behavior-based CEO incentive pay will be smaller in Stateowned companies. 


\section{Company performance}

The basic agency theory assumption is that compensation contracts can be written to give managers incentives to maximize the company's performance (Finkelstein and Hambrick, 1996). A large number of empirical studies have shown that CEO compensation systems focus on achieving this goal (Larcker, 1983).

H6. Companies that have CEO incentive systems perform better.

\section{Methodology}

\section{Dependent variables}

Some previous studies (Gómez Mejía, Tosi and Hinkin, 1987; Tosi and Gómez Mejía, 1989; Beatty and Zajac, 1994; Munter and Kren, 1995) use the ratio of fixed salary to total salary as "The proportion of behavior-based CEO incentive pay", while the ratio of variable salary to total salary represents "The proportion of CEO incentive pay based on outcomes".

Other authors (Ouchi, 1977; Fisher and Govindarajan, 1993; Bushman, Indjejikian and Smith, 1996) try to differentiate, within the variable part, between a portion based on subjective criteria (leadership abilities, human development, strategic ability, ...) and a portion established by objective criteria (economic indicators). According to these authors, behavior-based compensation will be the sum of the fixed salary and the variable part allocated using subjective criteria. The variable part determined using objective criteria represents the outcome-based CEO incentive pay. In this study, we used both methods to measure compensation.

In the first case, the dependent variable is fixed salary over total salary (FS/TS), which represents the proportion of behavior-based CEO compensation. We have used the natural logarithm of this variable, which we call log SF.

To calculate the dependent variable under the second assumption, we need to define what portion of variable compensation is determined by subjective criteria and what portion by objective criteria. To do this, we use a question from the questionnaire where we asked the correspondent to rate, from most important to least important $(1=$ most important, $5=$ least important), the factors that determine variable compensation:

1. Company financial performance

2. Individual goal achievement

3. Position in organization chart

4. Personal ability

5. Employee development

We used these data to run a factorial analysis, obtaining two main factors, shown in Figure 5.2. It is easy to see that the second factor can be associated with variable compensation based on objective criteria, while the first factor corresponds to variable compensation based on subjective criteria. 
Figure 5.2 Factor chart of objective and subjective criteria

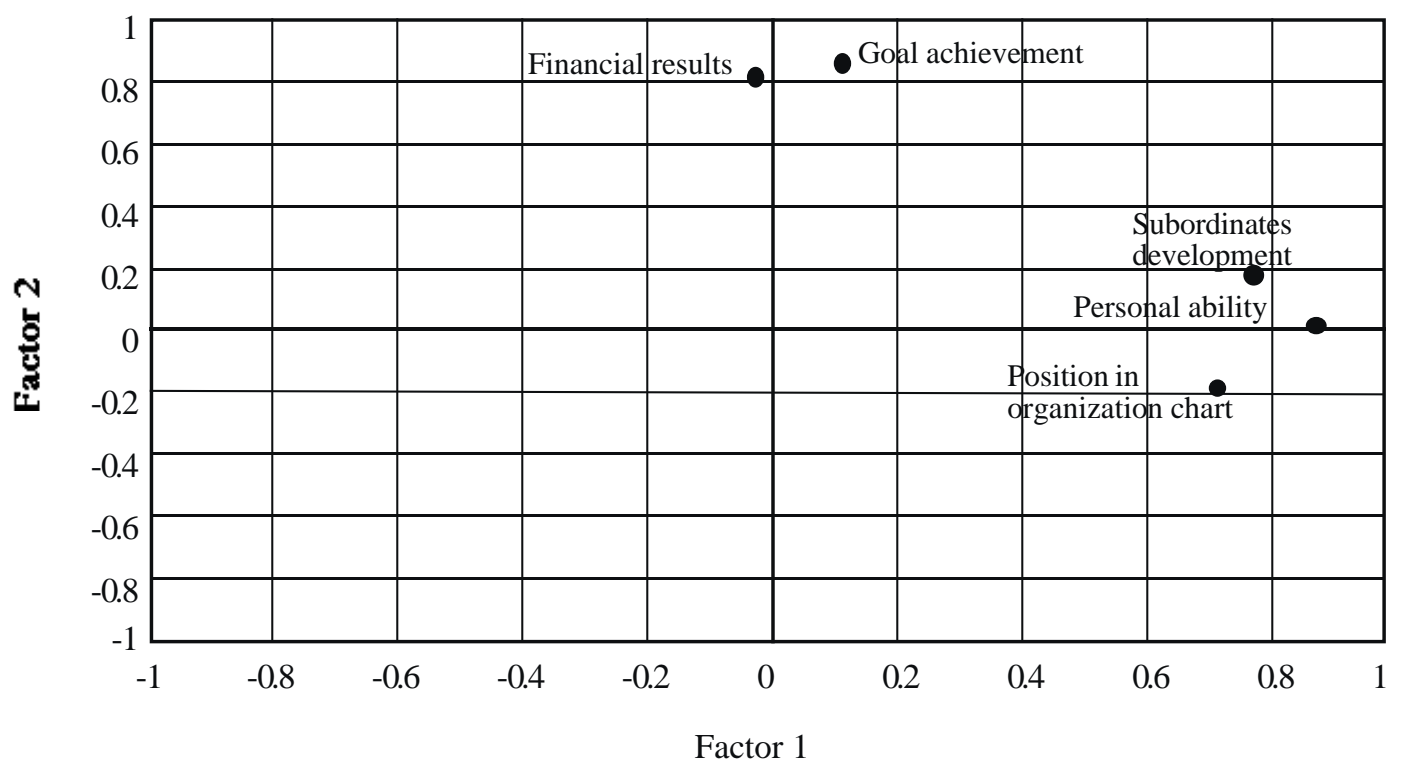

Using these factors, for the second set of assumptions, we define the proportion of behavior-based compensation as the sum of fixed salary and variable subjective salary, divided by total salary ((FS+VSS)/TS). Again, we use the natural logarithm, called log SFVS.

Independent or explanatory variables

The model's independent variables are:

- $\quad$ Proportion of outside directors (OD)

- $\quad$ Size (Employees/100) (EMP)

and the following dummy variables:

- $\quad$ Activity of the Board of Directors (ACT)

- $\quad$ Primary production or manufacturing industry (PROD)

- $\quad$ Functional structure (FUN)

- $\quad$ Listed on the stock market (LIS)

- $\quad$ Family firm (FAM)

- $\quad$ State-owned firm (ST)

To study the last hypothesis, the company's performance has been measured using two indicators: profit on sales $(\mathrm{P} / \mathrm{S})$ and profit per employee $(\mathrm{P} / \mathrm{E})$. 


\section{Results}

\section{Correlation matrix}

Table 5.4 shows the correlation matrix of independent variables. There are no major correlations between variables, which avoids co-linearity problems in the models:

Table 5.4. Correlation matrix of independent variables $(n=374)$

\begin{tabular}{|lrrrrrrrr|}
\hline Variable & ACT & OD & PROD & FUN & EMP & LIS & FAM & ST \\
ACT & 1 & & & & & & & \\
OD & 0.12 & 1 & & & & & & \\
PROD & -0.10 & -0.07 & 1 & & & & & \\
FUN & 0.01 & 0.02 & 0.15 & 1 & & & & \\
EMP & -0.01 & 0.02 & -0.02 & -0.10 & 1 & & & \\
LIS & 0.00 & 0.05 & 0.12 & -0.12 & 0.24 & 1 & & \\
FAM & 0.03 & -0.18 & 0.19 & 0.16 & -0.06 & -0.05 & 1 & \\
ST & 0.00 & 0.25 & -0.17 & 0.07 & 0.09 & -0.03 & -0.14 & 1 \\
& & & & & & & & \\
\hline
\end{tabular}

It is interesting to outline the most significant correlations. In particular, Stateowned companies are positively correlated with the proportion of outside directors, which is reasonable, because in State-owned firms Board positions are political. On the other hand, State-owned companies are negatively correlated with primary production activities and manufacturing, which is also reasonable, as most State-owned firms are in public services, transport and financing. Family businesses are negatively correlated with the proportion of outsiders on the Board. There is also a correlation between family companies and primary production activities and manufacturing, as well as with functional structure. Finally, there is a positive correlation between listed companies and the number of employees, which shows that listed companies tend to be larger.

\section{Empirical results}

We used multiple regression to test the first eight hypotheses. The following Table shows the results of the first model. The independent variable is log FS (fixed salary), which represents the proportion of behavior-based compensation. 
Table 5.5 Results of the first model

\begin{tabular}{|c|c|c|c|c|c|}
\hline \multicolumn{6}{|c|}{$\begin{array}{l}\text { Multiple linear regression } \\
\text { Companies which pay incentives } \\
\text { Dependent variable: } \log S \mathrm{SF} \\
\mathrm{F}=10,930 \quad \mathrm{p}=0.000 \quad \mathrm{R}^{2}=0.232\end{array}$} \\
\hline Variable & Coefficient & St. dev. & Beta & $\mathrm{t}$ value & $\mathrm{p}$ \\
\hline Ind. term & 1.884 & 0.01 & & 190.829 & $<0.001$ \\
\hline $\mathrm{ACT}$ & 0.020 & 0.008 & 0.127 & 2.427 & 0.015 \\
\hline OD & -0.001 & 0.000 & -0.049 & -0.895 & 0.371 \\
\hline PROD & 0.031 & 0.009 & 0.196 & 3.605 & $<0.001$ \\
\hline FUN & 0.015 & 0.009 & 0.091 & 1.690 & 0.091 \\
\hline EMP & -0.002 & 0.000 & -0.310 & -5.748 & $<0.001$ \\
\hline LIS & -0.012 & 0.013 & -0.047 & -0.868 & 0.386 \\
\hline FAM & -0.065 & 0.010 & -0.346 & -6.346 & $<0.001$ \\
\hline ST & 0.019 & 0.016 & 0.063 & 1.156 & 0.248 \\
\hline
\end{tabular}

The variable that measures the Board of Directors' activity shows a significant and positive relationship $(\mathrm{p}<0.05)$. It confirms the positive relationship between the Board of Directors' level of activity and behavior-based compensation foreseen in hypothesis $1 \mathrm{~b}$. We cannot confirm hypothesis 1a (positive relationship between behavior-based compensation and the proportion of outside directors). This relationship is not sustained by the model.

The positive relationship between behavior-based compensation and companies specializing in primary production (PROD) is confirmed $(\mathrm{p}<0.001)$, thus sustaining hypothesis $2 \mathrm{a}$. The same is found for hypotheses $2 \mathrm{~b}$ and $2 \mathrm{c}$. Both the FUN and the company size (number of employees -EMP-) variables are significant.

We cannot confirm hypotheses 3 and 5. In the former we conjectured a negative relationship between the proportion of behavior-based compensation and listed companies (LIS). In the latter we conjectured a negative relationship with State-owned companies (ST). The relationship is not significant in either case.

Finally, there is a significant negative relationship $(\mathrm{p}<0.001)$ between the proportion of behavior-based compensation and family business (FAM). With this result, hypothesis 4 is confirmed.

Table 5.6 shows the results of running multiple regression for the second model. We used log SFVS (fixed salary+subjective variable salary) as a dependent variable. 
Table 5.6. Results of the second model

\begin{tabular}{|c|c|c|c|c|c|}
\hline \multicolumn{6}{|c|}{$\begin{array}{l}\text { Multiple linear regression } \\
\text { Companies which pay incentives } \\
\text { Dependent variable: } \log (\mathrm{SF}+\mathrm{SVS})\end{array}$} \\
\hline Variable & Coefficient & St. dev. & Beta & $\mathrm{t}$ value & $\mathrm{p}$ \\
\hline Ind. term & 1.929 & 0.005 & & 376.277 & $<0.001$ \\
\hline ACT & 0.018 & 0.004 & 0.222 & 4.220 & $<0.001$ \\
\hline OD & -0.0001 & 0.000 & -0.054 & -0.976 & 0.329 \\
\hline PROD & 0.015 & 0.004 & 0.186 & 3.395 & 0.001 \\
\hline FUN & 0.010 & 0.005 & 0.111 & 2.049 & 0.040 \\
\hline EMP & -0.001 & 0.000 & -0.290 & -5.366 & $<0.001$ \\
\hline LIS & -0.009 & 0.007 & -0.069 & -1.264 & 0.206 \\
\hline FAM & -0.029 & 0.005 & -0.306 & -5.588 & $<0.001$ \\
\hline ST & 0.008 & 0.009 & 0.048 & 0.884 & 0.377 \\
\hline
\end{tabular}

Hypotheses 1b, 2a, 2b, 2c and 4 are confirmed again, strengthening our theoretical model and giving more validity to the conclusions reached earlier.

Finally, hypothesis 6 conjectured better performance for companies that apply CEO incentives, compared with those that do not. We ran a t-test for the difference in the averages of the two indicators of financial performance, profit over sales (P/S) and profit per employee $(\mathrm{P} / \mathrm{E})$. The following table shows the results of this analysis.

Table 5.7. Performance comparison between companies which apply incentives and those which do not

t-test $(n=465)$

\begin{tabular}{|c|c|c|c|c|}
\hline Variable(1) & \multicolumn{2}{|c|}{ With incentives $(n=374)$} & \multicolumn{2}{|c|}{ Without incentives $(n=91)$} \\
\hline $\begin{array}{l}\text { P / E (mill. ptas.) } \\
\text { P / S (\%) }\end{array}$ & $\begin{array}{c}\text { Average } \\
3.39 \\
6.13\end{array}$ & $\begin{array}{c}\text { Std. Dev. } \\
9.52 \\
6.84\end{array}$ & $\begin{array}{c}\text { Average } \\
0.83 \\
3.57\end{array}$ & $\begin{array}{c}\text { Std. Dev. } \\
6.30 \\
8.46\end{array}$ \\
\hline & \multicolumn{2}{|c|}{ Average diff. } & \multicolumn{2}{|c|}{$\mathrm{p}$} \\
\hline $\begin{array}{l}\text { P / E (mill. ptas.) } \\
\text { P / S (\%) }\end{array}$ & \multicolumn{2}{|c|}{$\begin{array}{l}2.56 \\
2.56\end{array}$} & $<0.05$ & \\
\hline
\end{tabular}

We can see that the average of $\mathrm{P} / \mathrm{E}$ and $\mathrm{P} / \mathrm{S}$ is larger in companies that apply incentives. In both cases the difference is statistically significant $(\mathrm{p}<0.05)$. These results confirm hypothesis 6 . 


\section{Discussion}

Table 5.8 shows the conclusions of our analysis of the determinants of CEO compensation. As in other parts of this paper, it is important to stress that while the number of outsiders on the Board is not significant, the monitoring hypothesis holds true when we use the Board's activity. Once again, composition is not a good indicator of governance excellence (Dalton et al., 1998).

Table 5.8 Conclusions

\begin{tabular}{|c|c|c|c|}
\hline & \multicolumn{2}{|r|}{ Hypothesis } & Conclusion \\
\hline \multirow[b]{2}{*}{ Monitoring } & H1a. & $\begin{array}{l}\text { The proportion of outsiders on the Board is positively } \\
\text { correlated with the proportion of behavior-based } \\
\text { CEO incentive pay. }\end{array}$ & Not proven \\
\hline & H1b. & $\begin{array}{l}\text { The Board's activity in governance decision-making } \\
\text { is positively correlated with the proportion of behavior-based } \\
\text { CEO incentive pay. }\end{array}$ & Proven \\
\hline \multirow{3}{*}{ Programmability } & $\mathrm{H} 2 \mathrm{a}$. & $\begin{array}{l}\text { The proportion of behavior-based CEO incentive pay } \\
\text { is larger in primary production and manufacturing } \\
\text { companies. }\end{array}$ & Proven \\
\hline & $\mathrm{H} 2 \mathrm{~b}$. & $\begin{array}{l}\text { The proportion of behavior-based CEO incentive pay is } \\
\text { larger in companies with a functional structure. }\end{array}$ & Proven \\
\hline & $\mathrm{H} 2 \mathrm{c}$. & $\begin{array}{l}\text { A company's size is negatively correlated with the proportion } \\
\text { of behavior-based CEO incentive pay. }\end{array}$ & Proven \\
\hline $\begin{array}{l}\text { Ability to measure } \\
\text { outcomes }\end{array}$ & H3. & $\begin{array}{l}\text { The proportion of behavior-based CEO incentive pay is } \\
\text { smaller in listed companies. }\end{array}$ & Not proven \\
\hline Risk aversion & H4. & $\begin{array}{l}\text { The proportion of behavior-based CEO incentive pay is } \\
\text { smaller in family companies. }\end{array}$ & Proven \\
\hline $\begin{array}{l}\text { Uncertainty about } \\
\text { the results }\end{array}$ & H5. & $\begin{array}{l}\text { The proportion of behavior-based CEO incentive pay is } \\
\text { smaller in State-owned companies. }\end{array}$ & Not proven \\
\hline $\begin{array}{l}\text { Company } \\
\text { performance }\end{array}$ & H6. & $\begin{array}{l}\text { Companies that have CEO incentive systems show } \\
\text { better performance. }\end{array}$ & Proven \\
\hline
\end{tabular}

Most of the basic hypotheses are confirmed. Board supervision and task programmability have a positive correlation with the proportion of fixed pay, size and risk aversion (family) a negative correlation.

The most interesting result is that, in spite of limited use, the use of incentives is correlated with better performance. As a consequence, we can well advise Spanish Boards of Directors to pay more attention to management compensation, to increase the proportion of variable pay, and to design it according to prevailing theoretical recommendations, even if these recommendations come from other contexts, as they are applicable to the case of Spain. 


\section{Conclusions}

This study is the first broad analysis of governance practices in Spain. Based on a powerful sample, it is very representative of the situation at the end of 1996. It may not be so in 1998, though. All indications in the analysis of the data show that the country is rapidly evolving and governance practices are changing and advancing. This is also confirmed by more anecdotal data from the press, such as the recent Olivencia report on best Board practices or the increasing use of incentive pay for top management compensation.

To summarize some of the implications of this paper:

1. Governance practices in Spain are far from effective. $42 \%$ of Boards are not active, only about $15 \%$ are participative, and even active Boards meet infrequently, devote too much time to reports, and do not get involved enough in the important issue of managing the top management team.

2. Some data are particularly interesting. $20 \%$ of the companies do not have an executive or management committee, concentrating executive power in the CEO or the Board itself. Less than $50 \%$ of the companies carry out formal appraisals of their key managers. And $20 \%$ of those that do never discuss them with the person being appraised. Finally, incentive pay is used in only a very small proportion of the companies. Surprising data, and even more so considering that we have been able to show that the three practices -management committee, appraisal, and incentive pay- are associated with improved corporate performance. Spanish companies would be well advised to follow them.

3. We were not able to show a significant association between better Board practices and corporate performance, but we believe this is merely a consequence of the novelty of the changes.

4. More and more studies are coming to the conclusion that most composition, characteristic or process variables are less relevant for effective governance than the actual will of the CEO and Board members to make governance a reality and to differentiate between governance and management, seeking a balanced distribution of power.

5. Governance practices in Spain are far from sophisticated, whether at Board level or, in a very specific way, with regard to the fundamental task of managing managers. Significant progress in appraisal and compensation systems is likely to take place within a short period of time. Everything seems to indicate that we will end up adopting practices developed in other cultural contexts such as the US, in spite of the institutional differences.

Spain was a closed economy for many years. Autarky made companies small and full of inefficiencies. The opening of the economy has led to a business revolution in Spain. The response has been striking. Business has rationalized and modernized, becoming increasingly focused and globalized. The gain in productivity has been tremendous. Most of the restructuring is complete. Now, companies must take the next step. And for this new stage, driven by the aggressive pursuit of growth and opportunities, by innovation and creativity, it is fundamental to develop the right governance practices.

The major surgery has been done. Now, it is necessary to advance in Board revitalization, appraisal and feedback, sharing and incentives. This is the way forward and Spain has a long way to go. But it is making progress. $\square$ 


\section{References}

Antonioni, D. (1996). "Designing an effective 360-Degree Appraisal Feedback process." Organizational Dynamics. Vol. Autumn: 24-38.

Aram, J.D. and Cowen, S.A. (1983). Information for Corporate Directors. The role of the Board in the Management Process, NAA Press, New York.

Baysinger, B. and Butler, H. (1985). "Corporate governance and the board of directors: performance effects of changes in board composition." Journal of Law, Economics and Organizations, vol. 1, no.1, pp. 101-124.

Baysinger, B. and Hoskinsson, R.E. (1990). "The composition of Boards of Directors and Strategic Control: Effects on Corporate Strategy." Academy of Management Review. Vol. 1990, 15, Iss. 1, Jan, pp. 72-87.

Beatty, R. and Zajac E. (1994). "Managerial incentives, monitoring and risk bearing: A study of executive compensation, ownership and board structure in initial public offerings." Administrative Science Quarterly, 39, pp. 313-335.

Bernardin, H.J., S. Dahmus and G. Redmon (1993). "Attitudes of First-line supervisors toward subordinate appraisals." Human Resource Management, Vol. 32: 315-324.

Bohl, D.L. (1996). "Minisurvey: 360-Degree Appraisals yield Superior Results, Survey Shows." Compensation and Benefits Review, Vol. September/October: 16-19.

Bushman, R., Indjejikian, R. and Samith A. (1996). "CEO compensation: the role of individual performance evaluation." Journal of Accounting and Economics, 21 (3) April, pp. 161-193.

Chaganti, R., Mahjan V. and Sharma, S. (1985). "Corporate board size, composition and corporate failures in retailing industries." Journal of Management Studies, 22, pp. 400-416.

Cochran, P.L., Wood, R.A. and Jones, T.B. (1985). "The composition of boards of directors and incidence of golden parachutes." Academy of Management Journal, 28, 664671.

Corrales, J.M. (1998). "Los sistemas de remuneración de los Directores Generales en las empresas españolas: factores que explican su composición." IESE. March 1998.

Daily, C.M. (1996). "Governance Patterns in Bankruptcy Reorganizations." Strategic Management Journal, Vol. 17, pp. 355-375.

Daily, C.M. and Dalton, D.R. (1994). "Bankruptcy and Corporate Governance: The Impact of Board Composition and Structure." Academy of Management Journal, Vol. 37, Iss. 6, Dec, pp. 1603-1617.

Daily, C.M. and Johnson, J.L. (1997). "Sources of CEO power and firm financial performance: A longitudinal assessment." Journal of Management, Vol. 23, Iss. 2, pp. 97-117. 
Dalton, D.R., Daily C.M., Ellstrand A.E. and Johnson J.L. (1998). "Meta-analytic reviews of board composition, leadership structure, and financial performance." Strategic Management Journal, Vol. 19, pp. 269-290.

Donaldson, G. (1995). "A New Tool for Boards: The Strategic Audit." Harvard Business Review, Vol. 73, Iss. 4, Jul/Aug, pp. 99-107.

Eaton, J. and Rosen, H. (1983). "Agency, delayed compensation, and the structure of executive remuneration." Journal of Finance, 39, pp. 1489-1505.

Eisenhardt, K. (1985). "Control: Organizational and economic approaches." Management Science, 31 (February), pp. 134-149.

Eisenhardt, K. (1988). "Agency and Institutional theory explanations: the case of retail sales compensation." Academy of Management Journal, Vol. 31, no. 3, pp. 488-511.

Eisenhardt, K. (1989). "Agency theory: An assessment and review." Academy of Management Review, Vol. 14, pp. 57-74.

Fama, E. (1980). "Agency problems and the theory of the firm." Journal of Political Economy, 88, pp. 288-307.

Finkelstein, S. and Hambrick, D. (1996). Strategic leadership: Top executives and their effects on organizations, ch. 8, pp. 261-305. West Publishing.

Fisher, J. and Govindarajan, V. (1993). "Incentive Compensation Design, Strategic Business Unit Mission, and Competitive Strategy." Journal of Management Accounting Review, 5 (Fall), pp. 129-144.

Gallo, M.A. and Cappuyns, K. (1997). "Boards of Directors in Family Business: Characteristics Regarding the Membership and Functioning Levels of Usefulness." 17th Annual International Conference, Barcelona.

Gedajlovic, E.R. and Shapiro, D.M. (1998). "Management and ownership effects: evidence from five countries." Strategic Management Journal, Vol. 19, pp. 533-553.

Ghorpade, J. and. Chen, M.M. (1995). "Creating quality-driven performance appraisal systems." Academy of Management Executive, Vol. 9, pp. 32-41.

Gómez-Mejía, Luis (1994). "Executive Compensation: A reassessment and future research agenda." In: Research in Personnel and Human Resources Management, Vol. 12, pp. 161-222. JAI Press.

Gómez-Mejia, Luis, Tosi, H. and Hinkin, T. (1987). "Managerial control, performance and executive compensation." Academy of Management Journal, vol. 30, no.1, pp. 51-70.

Govindarajan, V. and Gupta, A.K. (1985). "Linking Control Systems to Business Unit Strategy: Impact on Performance." Accounting, Organizations and Society, 10, pp. 51-66.

Hermann, M. (1987). "The executive's lament: On structuring CEO-Board relations in the public and non-profit sectors." Ohio State University's Quarterly Report, 11(3), pp. 1-10. 
Hill, S. (1995). "The Social Organization of Boards of Directors." British Journal of Sociology, Vol. 46, Iss. 2, pp. 245-278.

Holmstrom, B. (1979). "Moral Hazard and Observability." Bell Journal of Economics, 10 (Spring), pp. 74-91.

Holmstrom, B. and Milgrom, P. (1991). "Multitask principal agent analyses: Incentive contracts, asset ownership and job design." Journal of Law, Economics and Organization, 7, pp. 24-52.

Holthausen, R. and Larcker, D. (1991). "Financial performance and organizational structure." Working paper, University of Pennsylvania.

Ittner, C., Larcker, D. and Rajan, M. (1997). "The choice of performance measures in annual bonus contracts." The Accounting Review, Vol. 72, no. 2, pp. 231-255.

Johnson, R.A., Hoskisson, R.E. and Hitt, M.A. (1993). "Board of Directors Involvement in Restructuring: The Effects of Board Versus Managerial Controls and Characteristics." Strategic Management Journal, Vol. 14; Summer 1993, pp. 33-50.

Kesner, I.F. (1987). "Directors' stock ownership and organizational performance: An investigation of Fortune 500 companies." Journal of Management, 13, pp. 499-508.

Kesner, I.F. (1988). "Directors' Characteristics and Committee Membership: An investigation of Type, Occupation, Tenure and Gender." Academy of Management Journal, Vol. 31, Iss. 1, pp. 66-84.

Kesner, I.F. and Johnson, R.B. (1990). "Crisis in the Boardroom: Fact and Fiction." Academy of Management Executive, Vol. 4, Iss. 1, Feb., pp. 23-25.

Kesner, I.F., Victor, B. and Lamont, B. (1986). "Board composition and the commission of illegal acts: An investigation of Fortune 500 companies." Academy of Management Journal, 29, pp. 729-899.

Kosnik, R.D. (1987). "Greenmail: A study of board performance in corporate governance." Administrative Science Quarterly, 32, pp. 163-185.

Larcker, D. (1983). "The association between performance plan adoption and corporate capital investment." Journal of Accounting Economics, 5, pp. 9-30.

Latham, G.P. and Wixley, K.N. (1993). Increasing productivity through performance appraisal. USA, Addison-Wesley.

Lear, R.W. (1995). "Re-Engineering the Board." Chief Executive, Iss. 105, Jul/Aug, p.12.

Lorsch, J.W. and MacIver, E. (1989). Pawns or potentates: The reality of America's corporate boards. Boston, MA: Harvard Business School Press.

Meuter, F. Jr (1995). "What to ask about compensation." Directors \& Boards, Vol. 19, Iss. 2, pp. 38-43. 
Miller, P. and Norbun, D. (1986). "Directors in strategic crisis." In R. Lamb and P. Shrivastova (Eds.), Advances in Strategic Management, Vol. 4, pp. 95-110. Greenwich, CT: JAI Press.

Molz, R. (1985). "The role of the board of directors: Typologies of interaction." Journal of Business Strategy, Spring, pp. 86-93.

Molz, R. (1988). "Managerial Domination of Boards of Directors and Financial Performance." Journal of Business Research, Vol. 16, Iss. 3, May, pp. 235-249.

Munter, P. and Kren, L. (1995). "The impact of uncertainty by the board of directors on incentive system design." Managerial Auditing Journal, Vol. 10, pp. 23-34.

Norburn, D. (1986). "GOGOs, YOYOs and DODOs: Company directors and industry performance." Strategic Management Journal, 7, pp. 101-118.

Ouchi, W.G. (1977). "The relationship between organizational control." Administrative Science Quarterly, 22, pp. 95-113.

Park, J.C. (1995). "Reengineering Boards of Directors." Business horizons, Vol. 38, Iss. 2, Mar/Apr 1995, pp. 63-69.

Parker, H. (1996). "Re-Empowering the Board." Directors \& Boards, Vol. 20, Iss. 2, Winter 96, pp. 4-10.

Patton, A. and Backer, J. (1987). "Why won't directors rock the boat?" Harvard Business Review, Vol. 87, no. 6, pp. 10-18.

Pearce, J.A. (1983). "The relationship of internal versus external orientations to financial measures of strategic performance." Strategic Management Journal, 54, pp. 297-306.

Pearce, J.A. and Zahra, S.A. (1991). "The relative power of CEOs and boards of directors: Associations with corporate performance." Strategic Management Journal, Vol. 12, pp. $135-153$.

Pearce, J.A. and Zahra, S.A. (1992). "Board composition from a Strategic Contingency Perspective." Journal of Management Studies, Vol. 29, Iss. 4, pp. 411-438.

Pearson, Andrall E. (1985). "Six Basics for General Managers." Harvard Business Review, July-August 1989.

Pfeffer, J. (1973). "Size, composition and function of hospital boards of directors: A study of organization-environment linkage." Administrative Science Quarterly, 17, pp. 349-364.

Provan, J.G. (1980). "Board power and organizational effectiveness among human services agencies." Academy of Management Journal, 23, pp. 221-236.

Rechner, P.L. and Dalton, D.R. (1991). "CEO Duality and Organizational Performance: A Longitudinal Analysis." Strategic Management Journal, Vol. 12, Iss. 2, Feb., pp. 155-160. 
Schmidt, R. (1975). "Does board composition really make a difference?" Conference Board Record, 12(10), pp. 38-41.

Schmidt, R. (1977). "The board of directors and financial interests." Academy of Management Journal, 20, pp. 677-682.

Schmitt, F. (1996). "Study finds CEO salaries tracking performance." National Underwriter, (21 October), p. 48.

Thompson, J. (1967). Organization in Action. New York. McGraw Hill.

Tosi, H. and Gómez-Mejía, L. (1989). "The decoupling of CEO pay and performance: An agency theory perspective." Administrative Science Quarterly, 34, pp. 169-189.

Useem, M., Bowman, E.H., Myatt, J. and Irvine, C.W. (1993). "US Institutional Investors look at Corporate Governance in the 1990s." European Management Journal, Vol. 11, Iss. 2, Jun, pp.175-189.

Vance, S.C. (1964). Boards of directors: Structure and performance. Eugene, OR: University of Oregon Press.

Vance, S.C. (1968). The Corporate Directors: Structure and Performance. Eugene, OR: University of Oregon Press.

Vance, S.C. (1978). "Corporate governance: assessing corporate performance by boardroom attributes." Journal of Business Research, 6, pp. 203-220.

Vander Weyer, M. (1995). "The power behind the Putsch." Management Today, March, pp. 40-44.

Wilson, T. (1995). Innovative reward systems for the changing workplace. New York, MacGraw Hill.

Wood, M.M. (1983). "From the boardroom: What role for college trustees?" Harvard Business Review, 61(3), pp. 52-62.

Zahra, S.A. (1990). "Increasing the Board's Involvement in Strategy." Long Range Planning, Vol. 23, Iss. 6, pp. 109-117.

Zahra, S.A. and Pearce, J.A. II (1987). "A model of board of directors behavior and effectiveness." Proceedings of the Decision Science Institute Meeting, 2, pp. 11471149.

Zahra, S.A. and Pearce, J.A. II (1989). "Boards of Directors and Corporate Financial Performance: A Review and Integrative Model." Journal of Management, Vol. 15, Iss. 2, pp. 291-334.

Zahra, S.A. and Stanton, W.W. (1988). "The implications of board of directors composition for corporate strategy and performance." Journal of Management, 5 (2), pp. 229-236. 
Appendix 1

IESE

ORGANIZATIONAL GOVERNANCE

QUESTIONNAIRE

\section{GENERAL DATA}

1. Who answers the questionnaire:
a) Chairman of the Board
b) $\mathrm{CEO}$
c) Advisor
d) Manager
e) Other:

2. Sector:

3. Total Sales in 1995 (in mill. of PTAs):

4. Profits before taxes in 1995 (mill. PTAs):

5. Number of employees in 1995:

6. Type of ownership (mark one answer in each line):
a) Family
b) National
Non Family
c) State-Owned
Multinational
d) Listed on the stock market
Private
Not Listed on the stock market

\section{GOVERNANCE AND MANAGEMENT BODIES}

\section{BOARD OF DIRECTORS}

1. Type of Board in your company:
a) There is no Board
c) Nominal (There is a Board, but it has little influence)
b) Legal
d) Active

2. Number of directors on the Board:

a) Inside directors:

b) Outside directors:

3. Who appoints new directors to the Board?
a) Board of Directors
b) $\mathrm{CEO}$
c) Shareholders 


\section{Appendix 1 (continued)}

4. Criteria applied in selecting new directors, from most important to least important (1=most important, $5=$ least important):
a) Personality and character:
$\begin{array}{lllll}1 & 2 & 3 & 4 & 5\end{array}$
b) Position in organization chart:
$\begin{array}{lllll}1 & 2 & 3 & 4 & 5\end{array}$
c) Experience, training and knowledge:
12
d) Trust:
e) Other (please specify):

5. How often (per year) does the Board meet?

6. How long is each meeting of the Board?
a) Half morning or half afternoon
c) One day
b) One morning or one afternoon
d) Two days

7. Do directors receive information before meetings?
a) YES
b) $\mathrm{NO}$

8. What type of information do directors receive before each meeting?
a) Agenda of meeting
d) Information about important decisions
b) Minutes of last meeting
e) Other (please specify):
c) Financial situation

9. Percentage of time (approximate) devoted by the Board to the following activities:
a) Listening to reports:
b) Approving strategic decisions:
c) Approving statutory decisions:
d) Approving ordinary decisions:
e) Discussing critical issues: $\%$ time spent in meetings

\section{EXECUTIVE COMMITTEE}

10. Is there an Executive Committee in your company?
a) YES
b) NO

11. How many managers are there on the Committee?

12. Who appoints managers to the executive committee?
a) Board of Directors
b) $\mathrm{CEO}$
c) Shareholders 


\section{Appendix 1 (continued)}

13. Criteria applied in selecting managers, from most important to least important $(1=$ most important, 5 = least important):
a) Position in the organization chart

$\begin{array}{lllll}1 & 2 & 3 & 4 & 5 \\ 1 & 2 & 3 & 4 & 5 \\ 1 & 2 & 3 & 4 & 5 \\ 1 & 2 & 3 & 4 & 5 \\ 1 & 2 & 3 & 4 & 5 \\ 1 & 2 & 3 & 4 & 5\end{array}$

14. How often does the Committee meet?
a) Once a week
d) Once every two months
b) Once every two weeks
e) Once every three months
c) Once a month
f) Other (please specify):

15. How long is each Committee meeting?
a) Half a morning or half an afternoon
b) One morning or one afternoon
c) One day

16. Do members of the Committee receive information before each meeting?
a) YES
b) $\mathrm{NO}$

17. What kind of information do Committee members receive before each meeting?
a) Agenda of meeting
f) Labor background
b) Minutes of last meeting
g) Shareholder relations
c) Financial situation
h) Information about important decisions
d) Degree of goal achievement
e) Market information
i) Other (please specify) 
Appendix 1 (continued)

\section{MANAGEMENT BODIES' TASKS}

18. Complete the chart below to show the role of each management body in relation to the activities listed:
A= Approve
$\mathrm{D}=$ Decide
$\mathrm{P}=$ Propose
$\mathrm{I}=$ Inform

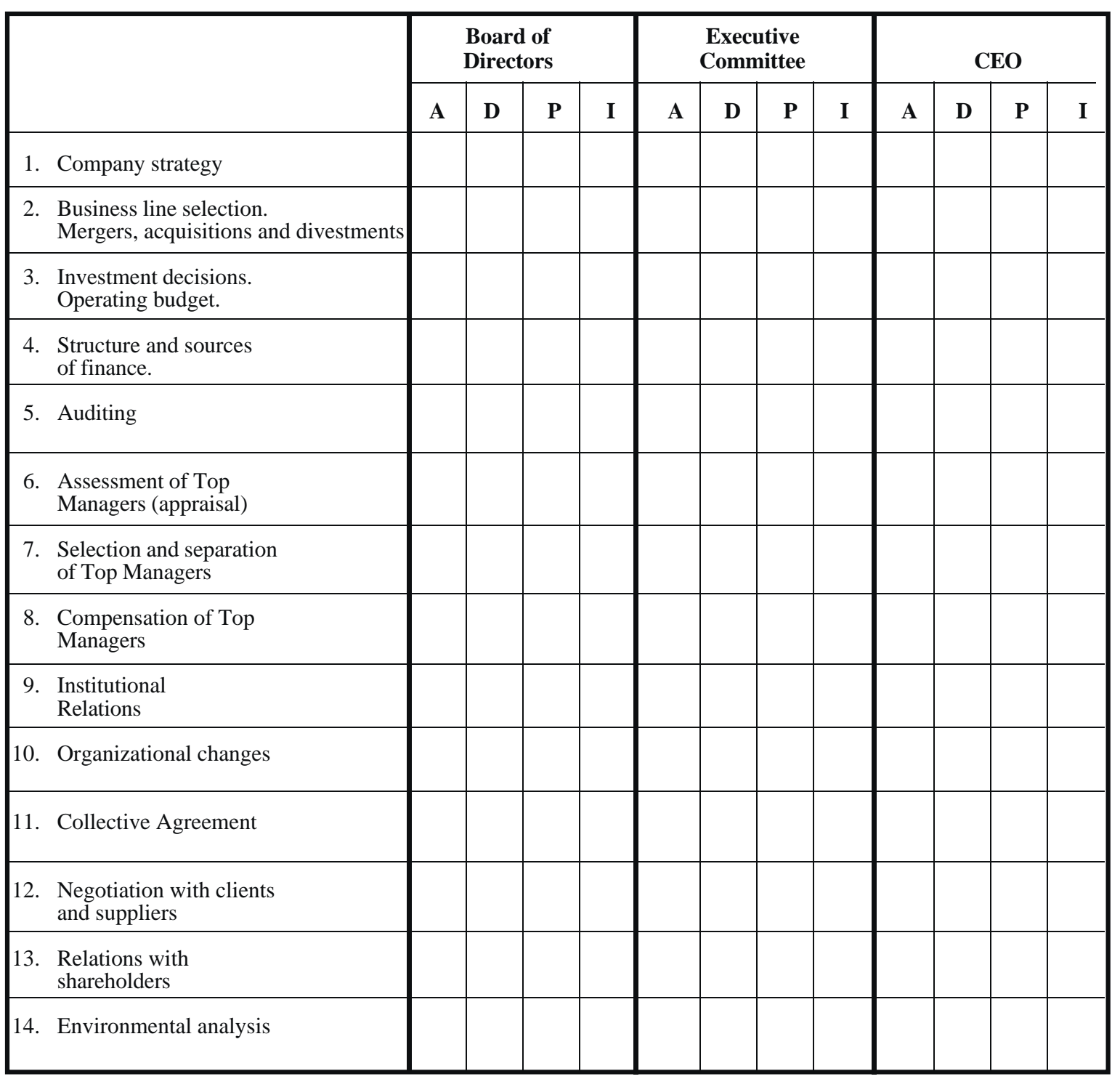


Appendix 1 (continued)

\section{ORGANIZATIONAL STRUCTURE}

19. What is the structure of your company?
a) Functional
b) Divisional
Product lines
Businesses
c) Matrix
Geographic areas
d) Network

20. How many management levels are there between CEO and operative staff?
a) Six or more
e) Two
b) Five
f) One
c) Four
g) None
d) Three

21. How long is it (in years) since the last change in the organizational structure of your company?

22. What factors influenced the decision to change the organizational structure?
a) Growth / Contraction
e) Changes in technologies
b) Disposals / acquisitions, Mergers
f) Changes in capital structure
c) Improvement of service or quality
g) Other factors (please specify)
d) Cost reduction

\section{MANAGER APPRAISAL AND COMPENSATION}

\section{APPRAISAL}

23. Does your company have a formal management appraisal system?
a) YES
b) NO (In this case, go to Compensation section)

24. For all managers other than the CEO, who participates in appraisals?
a) Immediate superior
e) Two or more superiors
b) Human Resources Director
f) $\mathrm{CEO}$
c) Board of Directors
g) Colleagues of the same level
d) Subordinates 
Appendix 1 (continued)

25. Factors used in management appraisal
a) General knowledge about management
b) Specific knowledge about the task
c) Knowledge about sector
d) Other knowledge
e) Specific goals of the unit
f) Specific goals of the business
g) Personal goals
h) Other goals
i) Other factors
j) Attitude towards customers
k) Attitude towards the firm
1) Attitude towards colleagues
m) Other attitudes
n) Company performance
o) Unit performance
p) Deviation from budget
q) Other results
r) Other

26. Points which best describe the characteristic of the formal appraisal process:
a) Formal documents
b) Secret appraisals
c) Appraisals are sent to the appraisee without discussing them
d) Appraisals are discussed with the appraisee

27. How often are appraisals conducted?
a) Once a year
b) Every six months
c) Every three months

28. Purpose of the appraisal process $(1=$ most important, $5=$ least important $)$ :
a) Career design and staff improvement plan in the firm
b) Assigning responsibilities
c) Fixing compensation
d) Other (please specify):

$\begin{array}{lllll}1 & 2 & 3 & 4 & 5 \\ 1 & 2 & 3 & 4 & 5 \\ 1 & 2 & 3 & 4 & 5 \\ 1 & 2 & 3 & 4 & 5\end{array}$




\section{Appendix 1 (continued)}

\section{COMPENSATION}

29. Please give the percentage of fixed and variable compensation (for the first three levels of management)

Level

1.

2.

3.
Fixed Compensation

(\% of total pay)
Variable Compensation

(\% of total pay)

30. Factors that influence fixed compensation $(1=$ most important, $5=$ least important $)$ :
a) Position in organization chart
b) Goal achievement
$\begin{array}{lllll}1 & 2 & 3 & 4 & 5\end{array}$
c) Potential
d) Knowledge and competencies
e) Style, age and seniority
f) Other factors (please specify)

$\begin{array}{lllll}1 & 2 & 3 & 4 & 5 \\ 1 & 2 & 3 & 4 & 5 \\ 1 & 2 & 3 & 4 & 5 \\ 1 & 2 & 3 & 4 & 5 \\ 1 & 2 & 3 & 4 & 5\end{array}$

31. Factors that influence variable compensation ( $1=$ most important, $5=$ least important):
a) Company performance
b) Individual goal achievement
$\begin{array}{lllll}1 & 2 & 3 & 4 & 5\end{array}$
c) Position in organization chart
$\begin{array}{lllll}1 & 2 & 3 & 4 & 5\end{array}$
d) Personal ability
$\begin{array}{lllll}1 & 2 & 3 & 4 & 5\end{array}$
e) Subordinates development
f) Other (please specify)
$\begin{array}{lllll}1 & 2 & 3 & 4 & 5\end{array}$
$\begin{array}{lllll}1 & 2 & 3 & 4 & 5\end{array}$
$\begin{array}{lllll}1 & 2 & 3 & 4 & 5\end{array}$

32. Main factors taken into account in measuring company performance (as used to fix managers' compensation):

(Select two factors)
a) ROA
b) ROE
c) Profits
d) Dividends
e) Share price
f) Market share
g) Economic Value Added (EVA)
h) Others 